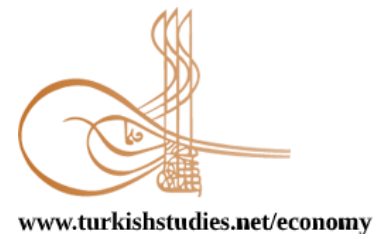

Turkish Studies - Economics, Finance, Politics

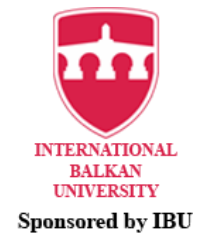

Research Article / Araştırma Makalesi

\title{
Soğuk Savaş Sonrası Dönemde Doğu Avrupa'nın Siyasi Dönüşümünün Bölgesel Bir Analizi: Otoriter Yönetimler ve Demokratikleşme Çabaları
}

\author{
Regional Analysis on Political Transformation of Eastern Europe in the Post-Cold War Period: \\ Authoritarian Regimes and Democratization Efforts
}

\author{
Hakan Karaaslan*
}

\begin{abstract}
This study aims to provide a regional analysis on the political transformation of Eastern Europe, by focusing mainly on the political developments in the Russian Federation, Ukraine, Moldova and Belarus, in the post-Cold War period. The analysis takes into account that Russian influence on the Eastern European countries in terms of political, economic and military aspects is one of the main dynamics of Eastern Europe. Within this framework, this study mainly argues that the democratization of Eastern European countries has been considerably limited. The main reason behind this is the fact that Russia has the ability to affect the domestic and foreign policies of Eastern European countries through political, economic, military and cultural instruments. In Russia and Belarus, the democratic transformation processes did not progress significantly in the post-communist period. Authoritarian governments have continued to exist in these two countries. Compared to Russia and Belarus, Ukraine and Moldova have engaged in efforts for democratic transformation. However, Ukraine and Moldova could not make a significant progress in democratization due to the ambivalence between Russian-oriented and the Western-oriented foreign policy preferences, and considerable impact of Russia on these countries through political, economic, military, cultural, social and historical factors. Due to Ukraine's inability to establish a common national identity and national consciousness; the loss of Crimea in 2014 and the emergence of internal conflict in the eastern regions of the country; and due to the separatist Transnistria conflict, the remaining Russian soldiers from the 14th Soviet Army, and military ammunition in Moldova, it was not possible for these two countries to focus on a real democratization process while dealing with these problems. Ukraine and Moldova have failed to realize democratic consolidation because of the Russian efforts to dominate Eastern Europe as a region including Ukraine and Moldova. The influence of Russia on the countries of Eastern Europe and its desire to establish control has resulted with very fragile structures in Ukraine's and Moldova's domestic and foreign policies.
\end{abstract}

Structured Abstract: There are geographically different definitions of the Eastern Europe as a region in the academic literature. Within the framework of this study, Eastern Europe, which is taken as a unit of analysis, includes the Russian Federation, Ukraine, Moldova and Belarus. As a scene of struggle between the great powers, Eastern Europe has been a center of geopolitical shifts throughout the history and thus it faced constant threats from the East and the West. Eastern Europe is located on the main transport and energy

\footnotetext{
* Dr. Öğr. Üyesi, Van Yüzüncü Yıl Üniversitesi, İktisadi ve İdari Bilimler Fakültesi, Uluslararası İlişkiler Bölümü Asst. Prof. Dr. Van Yüzüncü Yll University, Faculty of Economics and Administrative Sciences, Department of International Relations ORCID 0000-0002-2257-0202

hakankaraaslan@yyu.edu.tr Cite as/ Atıf: Karaaslan, H. (2020). Soğuk savaş sonrası dönemde Doğu Avrupa'nın Siyasi dönüşümünün bölgesel bir analizi: Otoriter yönetimler ve demokratikleşme çabaları. Turkish Studies - Economy, 15(3), 1445-1468. https://dx.doi.org/10.47644/TurkishStudies.42871

Received/Geliş: 13 April/Nisan 2020

Accepted/Kabul: 20 September/Eylül 2020

Copyright (C) INTAC LTD, Turkey

Checked by plagiarism software

Published/Yayın: 25 September/Eylül 2020

CC BY-NC 4.0
} 
corridors connecting Western Europe to Eurasia. This geographical location makes Eastern Europe a region where geo-strategic and geo-economic interests of global actors coincide.

After the collapse of the Soviet Union, Eastern European countries have faced various political, institutional, ethnic and socio-economic problems. One of the most important reasons for the chaos and instability in Eastern European countries in the post-communist period is difficulties occurred in the transition period from authoritarian rule to democratic government forms. It is generally observed that countries in Eastern Europe have remained distant from the Western European standards in areas such as functioning of democratic institutions, respect for human rights, freedom of media, free and fair elections and the principle of the rule of law.

This study aims to provide a regional analysis on the political transformation of Eastern Europe, by focusing mainly on the political developments in the Russian Federation, Ukraine, Moldova and Belarus, in the post-Cold War period. The analysis takes into account that Russian influence on the Eastern European countries in terms of political, economic and military aspects is one of the main dynamics of Eastern European politics. Within this framework, this study mainly argues that the democratization of Eastern European countries has been considerably limited. The main reason behind this is the fact that Russia has the ability to affect the domestic and foreign policies of Eastern European countries through political, economic, military and cultural instruments. In Russia and Belarus, the democratic transformation processes did not progress significantly in the post-communist period. Authoritarian governments have continued to exist in these two countries. Russia and Belarus have adopted the idea that democracy can only be acceptable to the extend it abide by their historical and cultural codes. This form of democracy can be called as a "managed democracy". Compared to Russia and Belarus, Ukraine and Moldova have engaged in efforts for democratic transformation. However, Ukraine and Moldova could not make a significant progress in democratization due to the ambivalence between Russian-oriented and the Western-oriented foreign policy preferences, and considerable impact of Russia on these countries through political, economic, military, cultural, social and historical factors.

Due to Ukraine's inability to establish a common national identity and national consciousness; the loss of Crimea in 2014 and the emergence of internal conflict in the eastern regions of the country; and owing to the separatist Transnistria conflict and the remaining Russian soldiers from the 14th Soviet Army and military ammunition in Moldova, it was not possible for these two countries to focus on a real democratization process while dealing with these problems. The point that should be mentioned especially for Ukraine is that the country has a divided appearance between the Euro-Atlantic bloc and Russia in terms of foreign policy preferences. Ukraine and Moldova have failed to realize democratic consolidation because of the Russian efforts to dominate Eastern Europe as a region including Ukraine and Moldova. The influence of Russia on the countries of Eastern Europe and its desire to establish control has resulted with very fragile structures in Ukraine's and Moldova's domestic and foreign policies.

The main findings of the article can be summarized as the following; the annexation of Crimea by Russia in 2014 and succeeding internal conflicts in Ukraine created a situation that seriously threatens the national sovereignty and territorial integrity of Ukraine. The Crimean crisis has emerged as a new conflict area between Ukraine and Russia in particular, which seems to have affected all Eastern Europe in general.

Since the early 1990s, Moldova has been facing a separatist conflict in the Transnistria region, located between the Dniester River and the Moldovan-Ukrainian border, in the eastern part of the country. This conflict is important for both Moldova's national security and the general security of the region. The failure of the Moldovan central government to solve this problem regarding the territorial integrity of the country prevents Moldova from becoming a more democratic state at the same time.

While trying to examine Eastern European politics, it is of great importance to evaluate Russia's relations with the countries of the region, which is one of the most determining dynamics of Eastern Europe. In Russian political and military circles, since 1992, a consensus has been reached on the importance of the former Soviet geography and on the creation of a foreign policy focusing mainly on this region. Within this framework, former Soviet republics in Eastern Europe started to gain importance for Russia. Russia's relations with Ukraine, Moldova and Belarus under the umbrella of the Commonwealth of Independent States (CIS) have become one of the main priorities of Russian foreign policy. 
Russia considers the policies and strategies of Western states towards Eastern Europe as a threat against its national security, regional security, and the stability of Eastern Europe. Russia is of the opinion that Western states, through geo-political and geo-economic activities in Eastern Europe, aims to weaken and prevent the activities of Russia to rebuild its hegemony in the former Soviet geography. From the Russian point of view, the strategies of the Western states tend to threaten both Russia's national interest in the region and the security of the whole region. For this reason, the prevention of military and political domination of Western powers in the former Soviet geography has been declared as one of the main objectives of Russian foreign policy. Russia wants to establish influence and control throughout Eastern Europe by using economic, political, military and cultural instruments. Russia's foreign policy mainly focuses on excluding the countries of the region from the Euro-Atlantic security alliance system.

Russia has a number of tools in order to realize the policies it has followed towards Eastern European countries. Political, military and economic instruments provide Russia with the opportunities to maintain Russian influence and control over the countries of the region. In this sense, Russia considers Eastern Europe as a primary asset in terms of its security realm. Considering the economic and energy dependence of the countries of the region on Russia and the Russian military presence in the countries of the region, it can be stated that Russia is highly likely to have considerable effects on every political developments in the Eastern European geography. The hegemony that Russia is trying to establish on other countries of the region is one of the most basic regional dynamics of Eastern Europe. Due to its important geopolitical and geo-strategic location, Eastern Europe witnesses a power struggle between the West and Russia, which aims to reestablish influence spesifically over the former Soviet geography and generally in international politics.

Keywords: International Relations, Area Studies, Eastern Europe, Russia, Ukraine, Moldova, Belarus, Political Transformation

Öz: Bu çalışma, Soğuk Savaş sonrası dönemde temel olarak Rusya Federasyonu, Ukrayna, Moldova ve Beyaz Rusya'da meydana gelen siyasi gelişmelere odaklanarak, Doğu Avrupa'daki siyasi dönüşüm süreçlerinin bölgesel bir analizini yapmayı amaçlamaktadır. Analiz, Doğu Avrupa'nın en temel dinamiklerinden birisi olan Rusya'nın bölge ülkeleri üzerindeki siyasi, ekonomik ve askeri etkileri dikkate alınarak yapılmaktadır. Bu çerçevede, makalenin temel argümanı, Soğuk Savaş sonrası dönemde Doğu Avrupa ülkelerinin demokratikleşme bakımından oldukça sınırlı bir gelişim göstermiş olmaları ve bu durumun temel nedeninin Rusya'nın siyasi, ekonomik, askeri ve kültürel birtakım araçlarla bölge ülkelerinin iç ve dış politikalarını doğrudan etkileme yetisine sahip olmasıdır. Bölge ülkelerinden özellikle Rusya ve Beyaz Rusya'da komünizm sonrası dönemde demokratik dönüşüm süreçleri ciddi bir ilerleme kaydetmemiştir. Bu iki ülkede, otoriter eğilimli yönetimler varlıklarını devam ettirmişlerdir. Ukrayna ve Moldova ise, diğer iki ülkeye nazaran demokratik dönüşüm açısından bir çaba içerisinde olmuşlar ancak bu ülkeler de özellikle dış politikada yön tercihleri bakımından Batı ile Rusya arasında kalmaktan ve Rusya'nın bu ülkeler üzerinde siyasi, ekonomik, askeri, kültürel, sosyal ve tarihsel faktörlerle şekillenmiş etkileri nedeniyle demokratikleșme konusunda kayda değer bir ilerleme sağlayamamıșlardır. Özellikle Ukrayna'nın ortak milli bir kimlik ve ulus bilinci tesis edememesi; buna ek olarak 2014'de Kırım'ın kaybedilmesi ve ardından da ülkenin doğu bölgelerinde bir iç çatışma ortamının oluşması; Moldova'da ise ayrılıkçı Transdinyester sorunu ve Moldova'da bulunan Sovyet döneminden kalma Rus askerleri ve askeri mühimmat nedeniyle bu iki ülkenin bu sorunlarla uğraşırken gerçek anlamda bir demokratikleşme sürecine yoğunlaşmaları çok mümkün olmamıştır. Ukrayna ve Moldova, Rusya'nın bölgeyi ve bu ülkeleri domine etme amaçlı politikaları nedeniyle içte demokratik konsolidasyonu gerçekleştirme konusunda başarılı olamamışlardır. Rusya'nın bölge ülkeleri üzerindeki etkisi ve kontrol kurma isteği, bölge ülkelerinin iç ve dış politikalarında oldukça kırılgan yapılara sahip olmaları sonucunu doğurmuştur.

Anahtar Kelimeler: Uluslararası İlişkiler, Bölge Çalışmaları, Doğu Avrupa, Rusya, Ukrayna, Moldova, Beyaz Rusya, Siyasi Dönüşüm 


\section{Giriş}

Literatürde Doğu Avrupa'ya ilişkin olarak yapılan akademik çalışmalarda coğrafi anlamda bölgeye ilişkin farklı tanımlamalar göze çarpmaktadır. Bir bölge olarak Doğu Avrupa eski Sovyet Cumhuriyetleri olan Rusya Federasyonu, Ukrayna, Moldova, Beyaz Rusya ile Baltık ülkelerini ve bugün Orta Avrupa'da yer alan Çekya, Slovakya, Macaristan ve Polonya gibi eski Doğu Bloğu ülkelerini kapsamaktadır. Bölgenin daha geniş olarak ele alındığı çalışmalarda ise bu ülkeler grubuna bazı Balkan ülkelerinin de eklendiği görülmektedir. Bu çalışma kapsamında analiz birimi olarak kabul edilen Doğu Avrupa bölgesine dâhil edilen ülkeler Rusya Federasyonu, Ukrayna, Moldova ve Beyaz Rusya ile sinırlandırılmıştır. Literatürde zaman zaman Avrupalı, Asyalı ve bu kategorilerin de dışında kendine has özellikleri ile farklı bir ülke olarak değerlendirilen Rusya Federasyonu ile ilgili sayısız yayın bulunmaktadır. Rusya'nın Avrupalı bir ülke mi, Asyalı bir ülke mi ya da bunlardan farklı bir uygarlığın temelini mi oluşturduğu tartışmalarına girmek bu makalenin boyutları dışında kalmaktadır. Ancak bu makale kapsamında Rusya Federasyonu Doğu Avrupa'da yer alan bir ülke olarak kabul edilmektedir. Zira Rusya tarihsel olarak Avrupa devletler sisteminin bir parçasıdır, Avrupa Konseyi ve Avrupa Güvenlik ve İşbirliği Teşkilatı katılımcı devletidir, Avrupa Birliği (AB) ile çok yakın siyasi ve ekonomik ilişkilere sahiptir ve son olarak da Atlantik güvenlik ittifakının temeli olan NATO (North Atlantic Treaty Organization-Kuzey Atlantik Antlaşması Örgütü) ile Rusya Federasyonu arasında ortak kurumlar oluş̧urulmuştur. Diğer yandan Ukrayna, Moldova ve Beyaz Rusya ile ilgili olarak özellikle Soğuk Savaş döneminde yapılan akademik çalışmalarda bu ülkelerin bir arada "Batılı Sovyet Cumhuriyetleri" olarak çalışıldığı görülmektedir. Soğuk Savaş sonrası dönemde ise Ukrayna, Moldova ve Beyaz Rusya gibi bölge ülkelerinin tek tek çalışılmalarına rağmen özellikle 2004 sonrasında bu ülkelerin 'Yeni Doğu Avrupa" olarak adlandırılan başlıklar altında analize tabi tutulmaya başlandığı görülmektedir. Sahip oldukları tarihsel miras ile siyasi, ekonomik, askeri ve kültürel bağlar ve ilişkiler göz önüne alındığında Rusya'nın bu üç bölge ülkesi ile ilişkilerinin de ağırlıklı olarak çalışıldığ görülmektedir.

Büyük güçler arasındaki mücadelenin bir anlamda sahnesi olan Doğu Avrupa tarih boyunca jeo-politik kaymaların merkezi olmuş ve bu nedenle hem doğudan hem de batıdan sürekli tehditlerle karşılaşmıştır (Stent, 2007a: 1). Doğu Avrupa, Bat1 Avrupa'yı Avrasya coğrafyasına bağlayan temel ulaşım ve enerji koridorları üzerinde bulunmaktadır ki, bu coğrafi konum Doğu Avrupa'yı büyük aktörlerin jeo-stratejik ve jeo-ekonomik çıkarlarının karşı karşıya geldiği bir bölge haline getirmektedir. Bu anlamda Doğu Avrupa olarak adlandırdığımız bölge tarih boyunca Almanya ve Rusya arasında bir güç mücadelesi alanı olagelmiştir. 2. Dünya Savaşı sonrası dönemde bölgede Sovyet etkisi altında komünist yönetimler kurulmuş ve ekonomi planlı bir şekilde merkezden yönetilmiştir. Soğuk Savaş döneminin sona ermesiyle birlikte Orta Avrupa'da yer alan Macaristan, Slovakya, Çekya ve Polonya AB ve NATO'ya üye olarak Batı Avrupa'ya siyasi, ekonomik ve askeri yönden eklemlenmeyi başarırlarken Doğu Avrupa'da yer alan Ukrayna, Moldova ve Beyaz Rusya'nın Batı Avrupa ile bütünleşmeleri Rusya Federasyonu'nun bu ülkeler üzerindeki siyasi, ekonomik ve askeri etkisi nedeniyle sınırlı kalmıştır.

Soğuk Savaş sonrası dönemde, Orta ve Doğu Avrupa devletleri yönlerini ya Batı Avrupa'ya çevireceklerdi ya da Rusya ile olan geleneksel ittifaklarına sadık kalmaya devam edeceklerdi. Soğuk Savaş'ın sona ermesi ile liberal demokrasi ve serbest piyasa ekonomisinin temellerini oluşturduğu Batılı değerlerin ve düşüncelerin benimsenmesinin ve buna ek olarak siyasi, ekonomik ve güvenlik odaklı Batılı uluslararası örgütlere katılma isteğinin, Orta ve Doğu Avrupa ülkelerinin sosyo-ekonomik ve siyasi alanlarda yaşayacakları dönüşüm ve değişim süreçleri için temel araçlar olacağı öngörülmekte idi. Batı kaynaklı değer, norm ve kurumların Orta ve Doğu Avrupa ülkelerinin modernleşme ve demokratikleşme süreçlerinde bir katalizör görevi göreceği varsayılmakta idi (Schmidtke ve Yekelchyk, 2008: 1). Bu çerçevede Doğu Avrupa ülkeleri, Doğu Bloğunun yıkılması ile birlikte "Avrupa'ya Dönüş" (Return to Europe) stratejisi ile ekonomik ve siyasi reformları gerçekleştirerek AB'ye ve NATO’ya üye olan Orta Avrupa ülkeleri 
ile eski Sovyet cumhuriyetleri olan Baltık ülkelerinden farklılaşmaktadırlar. Orta Avrupa ve Baltık ülkeleri 1990'lı yılların başından itibaren hızlı bir dönüşüm sürecine girmişler, bu bağlamda siyasi ve ekonomik reformları hızla hayata geçirerek 2000'li yılların başlarında AB'ye ve NATO'ya üye olmuşlardır. Buna karşın, tarihsel olarak devlet ve demokrasi geleneği ile piyasa ekonomisi tecrübesinden yoksun olan Doğu Avrupa ülkeleri için bu tarz bir dönüşüm sürecinin tamamlanmış olmasından bugün itibari ile söz etmek mümkün değildir (Vasily Astrov \& Peter Havlik, 2007: 127).

Soğuk Savaș sonrası dönemde Doğu Avrupa'da bağımsızlığını kazanan ve Sovyet kontrolünden kurtulan devletlerin siyasi ve ekonomik dönüşümleri, yani serbest piyasa ekonomisine, demokratik yönetime ve hukuk devletine dönüşüm süreçleri, bu ülkelerle ilgili en sancılı süreçler olarak karşımıza çıkmaktadır. Sovyetler Birliği’nin dağılmasından ve komünist sistemin yıkılmasından sonra, Doğu Avrupa'daki devletler çeşitli siyasi, kurumsal, etnik ve sosyoekonomik sorunlarla karşı karşıya kalmışlardır. Bu sorunların bölge ülkelerine yansımaları, ekonomik kalkınmanın gerçekleşmemesi, yüksek enflasyon ve işsizlik oranları, yoksulluk, suç oranlarında yükselme ve siyasi kargaşa şeklinde kendini göstermiştir. Belirtilen bu sorunlar, değişik seviyelerde olmakla birlikte bölgedeki bütün eski Doğu Bloğu ülkelerinde ortak olarak yaşanmıştır (Fraye, 1997: 168).

2021'de bağımsızlıklarının 30. yıldönümünü kutlayacak Doğu Avrupa ülkelerinin, tarihsel arka planları ve özellikle Soğuk Savaş sonrası dönemde içinde bulundukları siyasi, sosyoekonomik durum ve karşılaştıkları sorunlar itibariyle önemli farklılıklar gösterdiklerini ifade etmek gerekir. Buna karşın bölge ülkeleri, bölgenin bütünüyle bir analiz birimi olarak ele alınabilmesini sağlayan birtakım benzerliklere ve ortak sorunlara da sahiptir. Doğu Avrupa'yı bir bölge olarak ele almamızı sağlayan temel faktörler özetle şu şekilde sıralanabilir: İlk olarak, Doğu Avrupa ülkeleri Soğuk Savaş döneminde merkezden yönetilen planlı bir ekonomik sistem içerisinde yer almışlardır. Orta Avrupa ülkeleri, Sovyetler Birliği'nin dağılmasından sonra serbest piyasa ekonomisine geçiş sürecini tamamlarken Doğu Avrupa'da yer alan ülkeler bu sanc1lı sürecin zorluklarıly mücadele etmektedir. İkinci olarak, bütün Doğu Avrupa ülkeleri Sovyetler Birliği’nin totaliter siyasi sisteminin içerisinde olmuşlar ve bu sistemi bire bir uygulamak durumunda kalmışlardır. Soğuk Savaş'ın sona ermesinden sonra bölge ülkeleri için bütünüyle yeni bir politik sistem inşası kaçınılmaz olmuştur. Üçüncü olarak, bölge ülkeleri, Sovyet idaresi altında yıllarca süren ciddi ve yoğun bir ideolojik baskı döneminin ardından bağımsızlıklarını elde etmeleriyle beraber ideolojik bir boşlukla karşı karşıya kalmışlardır. 1990'lı yılların başlarında her çeşit siyasi görüş bölge ülkeleri içerisinde taraftar kazanım savaşına girmiştir. Dördüncü olarak, Doğu Avrupa ülkelerinin birçoğu geçmişten kaynaklanan çeşitli politik-etnik nitelikli sorunlara sahiptir. Bu sorunlar Soğuk Savaş döneminde arka plana itilebilmiş, ancak bölge ülkelerinin bağımsızlıklarını kazanması ile birlikte yeniden gün yüzüne çıkmıştır (Arbatov, 1997: 1-3). Beşinci ve son olarak da, Doğu Avrupa'da yer alan ülkelerin Soğuk Savaş döneminde Sovyet etkisi altında olmakla birlikte Batı ile yakın ilişkiler kurmuş olmaları bu bölgeyi bir bütün olarak incelememize imkân vermektedir (Bruchis, 1996: 23).

Sovyetler Birliği'nin dağılması ve Soğuk Savaş’ın sona ermesi ile birlikte Ukrayna, Moldova ve Beyaz Rusya literatürde "Batılı Yeni Bağımsız Devletler" (Western Newly Independent States) olarak adlandırılmıştır. Rusya Federasyonu, Ukrayna ve Beyaz Rusya tarafından 8 Aralık 1991'de Sovyetler Birliği'nin dağılmasıyla eş zamanlı olarak Bağımsız Devletler Topluluğu (BDT) kurulmuştur. Ukrayna, Moldova ve Beyaz Rusya, AB'nin "Komşuluk Politikası" (European Neighbourhood Policy) içinde yer almaktadırlar. Beyaz Rusya siyasi ve ekonomik yönden Rusya ile yakın bir ilişki içerisinde iken Moldova ve Ukrayna AB üyeliği hedefi başta olmak üzere Batı Avrupa ile daha yakın ilişkiler geliştirmek istemektedir.

Ukrayna, Moldova ve Beyaz Rusya, Balttk ülkeleri ile birlikte Sovyet Sosyalist Cumhuriyetler Birliği (SSCB) içinde özel bir coğrafyayı oluşturmuşlardır. Ukrayna, Moldova ve 
Beyaz Rusya'da, bu ülkelerin bulunduğu bölgeyi Sovyetler Birliği'nin Orta Asya ve Kafkasya'da bulunan cumhuriyetlerinden ayıran ve bu coğrafyada Batılı bir siyasi kültürün oluşumuna katk1 sağlayan önemli tarihsel deneyimlerin paylaşıldığını söyleyebiliriz. Bölge insanlarının farklı zamanlarda ve derecelerde Batılı komşuları ile yakın ilişkiler kurdukları görülmektedir. Bir başka ifadeyle bölge ülkeleri ile Batılı komşuları arasında tarihsel bir bağ gözlemlenmektedir (Solchanyk, 1990: 75).

Ukrayna, Moldova ve Beyaz Rusya diğer eski Sovyet Cumhuriyetleri ile pek çok benzer özellikler taşımaktadır. Bu ortak özellikler arasında başlıcaları; ortak bir Sovyet siyaset ve kültür mirasına sahip olma, demokrasinin ve demokratik kurumların zayıflığı ve yetersizliği, şeffaf olmayan ekonomik yapılar, devlet içinde ciddi oranlarda yolsuzluklar ile siyaset ve iş dünyası arasındaki çok yakın ilişkiler sayılabilir (Stent, 2007a: 2). Sosyal göstergelere ve insani gelişim endekslerine bakıldığında da bölge ülkelerinin Orta Avrupa ülkelerinden çok Rusya Federasyonu ile büyük benzerlikler taşıdığ 1 görülmektedir. Eski Sovyet Cumhuriyetleri olan bu ülkeler daha öncesinde de Çarlık Rusyası'nın bir parçası olmuşlar ve hem Rus İmparatorluğu'nun hem de Sovyetler Birliği'nin bünyesi altındaki bu uzun süreli tarihsel deneyimler, ülkelerin hem sosyal yapıları hem de inanç, değer ve kültürel özellikleri üzerinde çok önemli etkilerde bulunmuştur. İște bu etkileşimler Soğuk Savaş sonrası dönemde Ukrayna, Moldova ve Beyaz Rusya'nın Rusya ile çok güçlü siyasi, ekonomik, askeri ve kültürel bağlara sahip olmalarının devamını sağlamıştır. Aynı zamanda bu ülkelerin önemli oranda Rus enerji kaynaklarına bağımlılıkları söz konusudur (Mangott, 2007: 265). Buna ek olarak Ukrayna, Moldova ve Beyaz Rusya'da en büyük azınlık gruplarını etnik Ruslar oluşturmaktadır. Yine bu ülkelerde Rus olmayan nüfusun önemli bir bölümü de Rusça konuşabilmektedir (Schmidtke \& Yekelchyk, 2008: 3).

$\mathrm{Bu}$ çalışmada Soğuk Savaş sonrası dönemde bölgeye özgü gelişmeler siyaset boyutu üzerinden incelenmeye çalışılacaktır. Bu çerçevede, bölgede meydana gelen önemli siyasi değişimdönüşüm süreçleri ortaya konulmaya çalışllacaktır. Çalışmada bölgenin bir bütün olarak incelenmesi esas odak noktası olmakla birlikte, bölge ülkelerinde meydana gelen önemli gelişmeler bölgeyi ilgilendirdiği ve etkilediği ölçüde açıklanmaya çalışılacaktır.

\section{Doğu Avrupa'da Yönetimler ve Siyasi Dönüşüm Süreçleri}

Doğu Avrupa ülkelerinde komünizm sonrası dönemde ortaya çıkan karmaşanın ve istikrarsızlığın en önemli nedenlerinden birisi otoriter yönetimlerden demokratik bir siyasi yönetim biçimine geçiş sürecinde yaşanan zorluklardır. Bölge ülkeleri Sovyet baskısı altında demokratik gelenek ve kurumlardan yoksun kalmıştır. Yargının bağımsızlığı, parlamentonun yasama sürecinde kendi inisiyatifini özgürce kullanabilmesi, bireylerin özgürlüğü gibi konulardaki birtakım sorunlar bölge ülkelerinin demokratik bir yönetim biçimine geçiş sürecinde ortaya çıkan problemli noktalar olarak göze çarpmaktadır. Bölge ülkelerinin demokratik kurumların işlerliği, insan haklarına saygı, basın özgürlüğ̈̈, serbest ve adil seçimlerin yapılması ve hukukun üstünlüğü ilkesinin uygulanırlığı gibi alanlarda Batı Avrupa standartlarının çok altında kaldıkları görülmektedir. Doğu Avrupa'da demokratikleşme konusunun ele alınacağ 1 çalışmanın bu bölümünde öncelikle Doğu Avrupa'da halen ağırlığını koruyan otoriter yönetimler Rusya Federasyonu ve Beyaz Rusya üzerinden incelenecek, ardından bölgede özellikle 2000 sonrası dönemde demokratikleşme yönünde gösterilen çabalara ve gelişmelere Ukrayna ve Moldova özelinde değinilecektir. Yine bu başlık altında Soğuk Savaş sonrası dönemde Rusya Federasyonu'nun bölge ülkelerine yönelik politikaları özetlenmeye çalış1lacaktır.

\section{Doğu Avrupa'da Otoriter Yönetimler}

Doğu Avrupa'da bugün itibari ile otoriter yönetim anlayışının etkili olduğu bölge ülkelerinden birisi sadece bölgenin değil aynı zamanda uluslararası siyasetin de en önemli aktörlerinden birisi olan Rusya Federasyonu'dur. Soğuk Savaş sonrasında Rusya Federasyonu'nun 1993 yılında kabul edilen ilk anayasası Batı tipi parlamenter demokrasiye dayalı bir yönetim 
anlayışını benimseme eğiliminde idi. Yeni bağımsız bir devlet olarak Rusya Federasyonu, komünizm ve Çarlık dönemlerinde geçerli olan diktatör yönetimlerden sonra, Batı tipi demokrasiyi hayata geçirme ve kendisini daha demokratik bir yapıya kavuşturma yolunda adımlar atmıştır. Rusya Federasyonu'nun ilk devlet başkanı Boris Yeltsin 1999 yılının sonuna kadar görevde kalmış ve bu tarihten itibaren yerine Vladimir Putin geçmiştir. 2004 yılında yapılan devlet başkanlığı seçimini \% 70'in üzerindeki bir oy oranı ile kazanan Putin, dört yıl daha başkanlık görevini sürdürmüştür. 2008-2012 arası dönemde Rusya Federasyonu Başbakanlığı görevini yürüten Putin, 4 Mart 2012 tarihinde yapılan devlet başkanlığı seçimini bu kez de \% 60'ın üzerine çıkan bir oy oranı ile kazanarak üçüncü kez Rusya Federasyonu Devlet Başkanı olmuştur. Putin devlet başkanlığı dönemi boyunca ülkede ulusal hükümetin gücünü attırma, yerel idarelerin gücünü azaltma yolunda politikalar izlemekle, parlamentodaki siyasi partilerin etkilerini sinırlandırmak ve özellikle de medya tarafından yapılan eleştirilere karşı tolerans göstermeyen bir tutum içerisine girmekle eleştirilmiştir (Stent, 2007b: 424).

Stent'in ifade ettiği gibi, Putin Rusya'nın kendi koşullarına uygun bir demokrasi anlayışını benimseyeceğini ve bu nedenle Avrupa'yı bir model olarak almayacağını açıklamıştır. Rusya daha güçlü ve müreffeh olabilmek için yüzyıllar öncesinde olduğu gibi gerektiğinde Avrupalı demokratik normları, değerleri ve kurumları benimsemeyebilir. Ancak bu Avrupalı normların ve değerlerin benimsenmesinde Rusya kendine özgü koşulları da göz önüne alarak seçici davranacaktır (Stent, 2007b: 421). Putin, Rusya'nın gerçek bir demokrasiden çok "kontrollü" veya "yönetilen" bir demokrasiye (managed democracy) ihtiyacı olduğunu dile getirmiştir. Putin'in bu demokrasi anlayışı, devlet başkanını çok güçlü kıldığı, diğer anayasal kurumları zayıflattı̆̆ı ve basını devlet kontrolü altında tutmaya çalıștı̆̆ 1 için, muhalif çevreler tarafindan sıklıkla eleştirilmektedir. Bu tarz bir demokrasi anlayışının, Rusya'yı daha demokratik ve özgür bir devlet yapmaktan ziyade daha otoriter bir yönetim altına soktuğu dile getirilmektedir. Muhalif çevreler Rusya'nın Avrupa tipi bir demokrasi anlayışı ile değil kontrollü veya yönetilen demokrasi ve diktatörlük kuralları ile yönetildiğini dile getirmektedirler. Bu eleştirilere göre, Putin ile birlikte Rus siyasi sistemi, büyük oranda yolsuzluk, özel mülkiyete ait malların kamulaştırılması, basın özgürlügünün kısıtlanması, siyasi elitlerle iş dünyası elitleri arasında şeffaf olmayan ilişkilerin var olması, siyasi gücün merkezileştirilmesi ve devlet güvenlik birimlerine daha fazla rol verilmesi gibi hususlar sergilemeye başlamıştır.

Diğer taraftan, Putin ülkesini 1990'ların kargaşa ve belirsizlik ortamından çıkararak istikrarı ve ekonomik büyümeyi sağladığı için halkın gözünde çok popülerdir. Rus halk1 1990'l1 yıllar boyunca Yeltsin'in devlet başkanlığ 1 süresince demokratikleşme politikalarına paralel olarak ülkenin daha güvensiz ve istikrarsız bir hale dönüştüğü kanısındadır. Putin ile birlikte güvenlik ve istikrarın yeniden geldiği ve Rusya'nın uluslararası sahnede küresel bir aktör olarak tekrar eski gücünü ve saygınlığını kazandığı düşünülmektedir (Stent, 2007b: 424).

Rusya Avrupa Konseyi üyesidir. Bununla birlikte Rusya'nın ülke içinde insan hakları ve demokrasi alanında Batı Avrupa standartlarını yakalamadaki başarısızlığı ve özellikle de Çeçenistan Sorunu ile ilgili olarak izlemiş olduğu bazı politikalar Avrupa Konseyi'nin şiddetli eleştirilerine maruz kalmıştır (Baranovsky, 2000: 453). Rusya'nın demokratikleşmesi, insan haklarına saygılı bir ülke olması, çoğulcu bir topluma dönüşmesi, ülke içinde hukukun üstünlüğü ilkesinin uygulanması gibi alanlarda yapılan reformlar Batı tarafindan yetersiz bulunmaktadır. Bugün itibari ile Rusya'nın siyasi ve ekonomik sisteminin işleyişinin, Avrupa'nın demokrasi normları ve değerleri ile ne kadar uyumlu hale gelebileceği sorusuna bir cevap aranmaktadır (Stent, 2007b: 431).

Doğu Avrupa'da katı bir otoriter yönetim anlayışı ile yönetilen ülkelerden birisi de Beyaz Rusya'dır. Beyaz Rusya 1990'ların başından itibaren yeni ve kırılgan bir demokrasiden otoriter bir yönetime geçiş süreci yaşamıştır. Rudling, komünizm sonrası dönemde Beyaz Rusya'nın siyasi gelişimini üç ayrı devreye ayırarak incelemektedir. Bu üç dönem, 1991-1994 dönemi bağımsızlık 
ve demokratik ulusal kurumların kurulması; 1994-1996 dönemi devlet başkanı ve parlamento arasındaki çatışma, başkanlık yetkilerinin kuvvetlendirilmesi, demokratik kurumların ve bağımsızlığın zayıflatılması ve son olarak 1997'den günümüze kadar olan dönemde tek adam otoriter yönetiminin egemen olması şeklinde özetlenebilir (Rudling, 2008: 55).

Soğuk Savaş sonrası dönemin ilk yıllarında Beyaz Rusya siyasi olarak ikiye bölünmüş bir görünüm sergilemekte idi. Bir yanda Rus ve Sovyet nostaljisi yanlıları, diğer yanda ise Rus karşıtı Batı yanlısı milliyetçiler yer alıyordu. Siyasi ortamdaki bu katı kutuplaşma üçüncü bir siyasi gücün ortaya çıkmasına yol açmıştır. 1994 yılından itibaren bu yeni siyasi gücün adı bugün halen devlet başkanlığ görevini sürdüren Aleksandr Lukaşenko olmuştur. 1994'e kadar Beyaz Rusya, Beyaz Rusya Sovyet Sosyalist Cumhuriyeti Yüksek Sovyeti'nin siyasi yapıları tarafindan yönetilmiştir. Hükümet çok büyük oranda eski sistemi ve nomenklaturayı temsil eden komünistlerden oluşmuştur. Beyaz Rusya'nın yeni anayasası 15 Mart 1994 tarihinde yürürlüğe girmiştir. En güçlü başkan adaylarından Viacheslau Kebich Sovyetler Birliği'nin dağılmasının büyük bir hata olduğunu ifade ederek Sovyetler Birliği'ni yeni bir formda yeniden oluşturmak adına söz vermiştir. Kebich'e karşı başkanlık yarışında aday olan Lukaşenko ise "Ne sol, Ne Sağ, sadece Halkla" şeklinde ifadesini bulan sloganı kullanarak oldukça başarılı bir seçim stratejisi izlemiştir. Lukaşenko seçim çalışmaları sürecinde Rusya'daki Batı karşıtı siyasi güçlerle yakın ilişkiler kurmuştur. Bu bağlantılara ek olarak Beyaz Rusya Popular Front'un düşüşü ve seçim sürecinde yapmış olduğu stratejik hatalar 1994 devlet başkanlığ 1 seçimlerinde Lukaşenko'yu başarıya ulaştırmıştır. Seçim döneminde Beyaz Rusya Popular Front yolsuzluk ve ekonomi politikalarının başarısızlığı gibi nedenlerden dolayı toplumdaki desteğini iyice yitirmiştir (Rudling, 2008: 63).

Büyük ölçüde serbest ve adil olarak değerlendirilen 1994 Beyaz Rusya devlet başkanlığ1 seçiminin ilk turu neticesinde bağımsız aday Lukaşenko oyların \% 45,1'ini almıştır. Seçimlerin ikinci aşamasında Lukaşenko ve Kebich yarışmış ve Lukaşenko oyların \% 80,1'ini alarak devlet başkanı seçilmiş̧ir. Bu dönemden itibaren Beyaz Rusya'da Lukaşenko idaresi altında otoriter bir yönetim şekli oluşturulmaya başlanmıştır. Lukaşenko 1994'den itibaren başkanlığını yeni diktatöryel güçlerle kuvvetlendirirken, sistematik olarak parlamentoyu zayiflatma stratejisi izlemiştir. Lukaşenko amaçlarını gerçekleştirebilmek için referandum mekanizmasını sistematik bir araç olarak kullanmaya başlamıştır. Ülkenin bayrağ 1 ve arması da dâhil olmak üzere Beyaz Rusya ulusuna ait sembolleri ortadan kaldırarak yerine eski Sovyet simgelerini koymuştur. Aynı zamanda resmi azınlık dili olan ancak nüfusun büyük çoğunluğu tarafindan konuşulan Rusça, Beyaz Rusya dili ile eşit statüye getirilmiştir.

Lukaşenko'nun temel amacı parlamenter sistemi zayıflatmak olmuştur. Lukaşenko tarafından yeni bir anayasa hazırlatılmış ve yeni anayasa ile devlet başkanının görev süresi iki yıl daha uzatılmış, buna ek olarak üyeleri devlet başkanı tarafından belirlenen yeni bir meclis oluşturulmuştur. Bu yeni meclisi kontrolü altına alan Lukaşenko varolan Anayasa Mahkemesinin yerine başkanını kendisinin atadığı yeni bir mahkeme kurulmasını sağlamıştır. Hukuk ve siyaset alanlarında yapılan bu değişiklikler devlet başkanının gücünü artırırken parlamentonun gücünü ve yetkilerini iyice sınırlandırmıştır. Yapılan bu değişiklikler 24 Kasım 1996 tarihinde yapılan referandumla oy kullananların \% 70'i tarafından kabul edilmiştir. Bu referandum Avrupa Güvenlik ve İşbirliği Teşkilatı (AGIT), Avrupa Birliği, Amerika Birleşik Devletleri ve Avrupa Konseyi tarafından şiddetle eleştirilmiş ve yapılan bu referandumun meşruiyeti sorgulanmıştır. Lukaşenko 1996 yılı içinde parlamentoyu feshederek güçler ayrılığı ilkesinin sadece kâğıt üzerinde olduğu yarı diktatöryel bir yönetim anlayışı getirmiştir. Ekim 2004'de anayasaya ilişkin olarak yapılan üçüncü referandum sonucunda devlet başkanlığı görevi için en fazla iki dönem sınırlaması kaldırılmış ve Lukaşenko'ya yaşam boyu başkanlık yolu açılmıştır (Rudling, 2008: 65-66).

Beyaz Rusya'da özellikle demokratikleşme alanındaki olumsuz gelişmeler Batının endişelerine yol açmaktadır. Aleksandr Lukaşenko'nun 1994 tarihinde iktidara gelmesinden bu yana, Beyaz Rusya siyaset ve ekonomi alanlarında çok büyük ölçüde Sovyet etkilerini devam 
ettirmiş ve ülke içinde muhalefete imkân tanınmamıştır. Bugün itibari ile Beyaz Rusya'nın AvrupaAtlantik ittifak sistemine katılmak gibi bir stratejisi olmadığı gibi, ülkenin yönetimi antiAmerikancidır ve 1996'dan bu yana Rusya Federasyonu ile birçok konuda ittifak halindedir (Stent, 2007a: 10). Lukaşenko dönemi ile birlikte Beyaz Rusya'nın Batı ile ilişkileri çeşitli diplomatik krizler nedeniyle sürekli olarak kötüye gitmiştir. Lukaşenko'nun Libya, Suriye, Irak ve İran ile yakın ilişkiler kurması Beyaz Rusya'nın uluslararası alanda büyük ölçüde izole olmasına yol açmıştır. Nitekim Beyaz Rusya, Avrupa Konseyi üyesi olmayan tek Avrupa ülkesidir (Rudling, 2008: 66-68).

Rudling, Soğuk Savaş sonrası dönemde Beyaz Rusya'nın eski Sovyet uydusu Orta Avrupa ülkeleri ve eski Sovyet Cumhuriyetleri olan Baltık ülkelerinden farklı yönde siyasi gelişmeler yaşadığını, komşuları demokratik ve çoğulcu bir topluma doğru yol alırken Beyaz Rusya'nın otoriter bir yönetim altına girdiğini belirtmektedir. Rudling'e göre Beyaz Rusya Batıdaki komşularından çok Sovyet sonrası Orta Asya devletleri ile benzerlikler göstermektedir. Beyaz Rusya, $\mathrm{AB}$ ve $\mathrm{ABD}$ tarafından "Avrupa'nın son diktatörlüğü" olarak adlandırmaktadır (Rudling, 2008: 55).

Nitekim Beyaz Rusya'da Aralık 2011'de yapılan devlet başkanlığı seçimlerinde oyların yüzde 80'ini alan şuanki devlet başkanı Aleksandr Lukaşenko dördüncü kez devlet başkanı seçilmiştir. Seçimlerin adil ve özgür bir ortamda geçmediğini iddia eden muhalefet yanlılarının yaptıkları protesto gösterileri ise seçim sonrasında meydana gelen en önemli gelişme olmuştur. Seçimlerde gözlemci olarak bulunan AGITT ise ülkenin yarısından fazlasında seçimlerin şeffaf olmadığını açıklamıştır. Seçim sonrasında yaşanan ve ABD ile AB tarafından da eleştirilen bu gelişmeler Beyaz Rusya'nın demokratik bir yönetime geçiş sürecinde hangi noktada olduğunu göstermesi bakımından son derece önemlidir (Seçim İsyanına Demir Yumruk, Milliyet, 21.12.2010).

\section{Doğu Avrupa'da Demokratikleşme Çabaları}

Doğu Avrupa'da otoriter yönetim anlayışlarının ağırlığını koruduğu Rusya ve Beyaz Rusya'ya karşın bölgenin en önemli ülkelerinden birisi olan Ukrayna'da özellikle 2004 y1lından itibaren demokrasiye geçiş çabalarının yoğunluk kazandığı görülmektedir. Ukrayna'daki iç politika gelişmelerine baktığımızda, 2004 yılında yapılan devlet başkanlığı seçimlerinin hem Ukrayna içinde hem de Rusya ile Batı dünyası arasında ciddi bir krize neden olduğu görülmektedir. Seçim sonuçlarının açıklanması ile birlikte Rusya'nın desteğini alan başkan adayı Viktor Yanukoviç'in seçimi kazandığı ilan edilse bile Batı ülkeleri ve uluslararası seçim gözlemcileri seçimlerin adil geçmediğini dile getirmiş ve Ukrayna halkı da yoğun protesto gösterilerinde bulunmuştur. Bunun üzerine yenilenmek zorunda kalan seçimden bu kez Batının desteğini alan başkan adayı Viktor Yuşçenko galip ayrılmıştır. O dönemde Ukrayna'da ve daha sonrasında Gürcistan ve Kırgızistan gibi eski Sovyet Cumhuriyetlerinde yaşanan buna benzer gelişmeler "Turuncu Devrim" (Orange Revolution) ya da "Kadife Devrimler" olarak adlandırılmıştır. Seçimlerde yaşanan bu problemler Ukrayna içinde halkın Rusya veya Batı yanlısı olarak bölündüğünü göstermesinin yanı sıra Ukrayna'nın bundan böyle Batılı ülkeler ile Rusya arasında bir güç mücadelesi alanına döneceğini de işaret etmekteydi (Donaldson \& Nogee, 2005: 191).

Turuncu Devrim Ukrayna için demokrasinin yerleşmesi ve geliştirilmesi ile ülkenin AvrupaAtlantik sistemine entegre olması gibi hususlar bakımından ülke içinde iyimser bir hava doğurmuştur. Ukrayna'nın Batı ile ilişkileri gelişmektedir. 2006 yılında yapılan seçimlerin özgür ve adil olduğu görüşü mevcuttur. Partiler arasında siyasi bir rekabet ve basın ortamında çoğulculuk olduğu görüşü mevcuttur. Ukrayna ekonomisi yüksek oranlarda büyüme rakamları kaydetmiştir. Stent'e göre bütün bu gelişmeler, doğusu ve batısı arasında devam eden farklılıklara rağmen Sovyetler Birliği'nin dağıldığı döneme oranla Ukrayna'nın ulusal kimliğinin gelişim göstermesine imkân vermiştir (Stent, 2007a: 9). Mangott'a göre ise, Ukrayna halkı sivil haklarını elde etmesine rağmen, Ukrayna'da demokratikleşme süreci tamamlanmış olmaktan çok uzaktır. Anayasal çerçeve 
oturtulmamıştır, çoğulcu bir toplum oluşmamıştır, siyasi kurumlar ve karar alma mekanizmaları zayıftır. Ukrayna bugün itibariyle liberal demokrasinin temelini oluşturan anayasal liberalizmden yoksundur (Mangott, 2007: 271).

Kuzio'nun ifadesiyle, Soğuk Savaş sonrası dönemde Ukrayna'nın siyaset kültürü ve politika yapımında Sovyet dönemine ait tarihsel tecrübelerin etkisi devam etmiştir. Kuzio'ya göre Ukrayna'nın Sovyet döneminden devraldığı kurumlar ve yapılar bağımsız bir devlet olabilmek için yeterli değildi. Ukrayna bağımsız bir devletin sahip olması gereken yeterli bir dışişleri teşkilatına sahip değildi. Aynı şekilde bürokrasi kadrolarında yer alan devlet görevlileri de yeterli donanıma sahip değildi (Kuzio, 2007b: 32-34). Sonuç itibariyle Ukrayna'nın işleyen bir parlamenter sistem, özgür basın, güçlü bir sivil toplum, siyasi partilerin kurumsal yapılanmaları, demokratikleşme, hukukun üstünlügü ilkesinin kurumsallaştırılması, yolsuzluklarla mücadele ve ekonomik kalkınma için yapılması gereken siyasi, ekonomik, hukuksal ve sosyal reformları hayata geçirmede ağır kaldığı gözlemlenmektedir. Örneğin Kuzio, 2004 yılındaki Turuncu Devrim sonrasında Ukrayna'da iki kilit alanda, yolsuzlukların önlenmesi ve hukuk devleti alanlarında herhangi bir reform ve gelişme olmadığını dile getirmektedir (Kuzio, 2007b: 33).

2005 yılında dönemin Ukrayna Dışişleri bakanı Boris Tarasyuk ülkesinin bundan böyle Avrupa-Atlantik ittifakına ve AB'ye katılmayı hedefleyen bir dış politika izleyeceğini ilan etmiştir. Ukrayna'daki siyasi partilerin büyük çoğunluğunun Ukrayna'nın $\mathrm{AB}$ üyeliğine destek verdikleri görülmektedir. AB'ye üye olarak demokratikleşmenin ve hayat standartlarının yükseleceği düşünülmektedir. Buna karşın NATO üyeliği konusunda Ukrayna içinde tam bir görüş birliğinden söz etmek mümkün değildir (Kuzio, 2007a: 89-90).

Ukrayna, 2004'deki “Turuncu Devrim" sonucunda demokratik yönetime geçiş sürecine girmiş ancak Yuşçenko'nun Batı yanlısı stratejisi 2006 yılında yapılan seçimler sonrasında Rusya ile yakın ilişkiler yanlısı siyasi elitler tarafından dengelenmiştir. 2010 yılında yapılan devlet başkanlığı seçimlerinde Rusya yanlısı Viktor Yanukoviç devlet başkanı olmuştur. Ülkedeki bu siyasi bölünmüşlük, Ukrayna'nın stratejik tercihlerini belirsizleştirmektedir (Schmidtke \& Yekelchyk, 2008: 2). Bu bağlamda Ukrayna, Rusya için diğer ülkelere oranla daha farklı bir anlam taşımaktadır. Rusya Ukrayna'nın bağımsızlığını ilan etmesinden sonra, Ukrayna ile siyasi, ekonomik ve askeri alanlarda yakın işbirliği ve ortaklık ilişkisi içerisinde olmak istemiştir. Rusya'nın Ukrayna'ya yönelik politikasının ana hedefi Ukrayna'yı Avrupa-Atlantik ittifakının dışında tutmak yani temel olarak NATO'ya üye olmasını engellemektir (Donaldson \& Nogee, 2005: 190).

2013 yılı Kasım ayında Ukrayna ve Rusya arasında başlayan gerginlik, Kırım'ın Rusya tarafından ilhakı ile ulusal ve bölgesel dinamikleri aşıp uluslararası bir mahiyet kazanmıştır. Kasım 2013'de Ukrayna Devlet Başkanı Yanukoviç'in AB ile Ukrayna arasında yapılacak "Doğu Ortaklığı Antlaşması"nı imzalamaktan son anda vazgeçmesi ile başlayan kriz kısa süre içerisinde bölgesel ve küresel birtakım aktörlerin de eklenmesiyle uluslararası bir boyut kazanmıştır. Bu kararın ardından Ukrayna'nın başkenti Kiev, devlet başkanının bu kararını eleştiren çok şiddetli protesto hareketlerine sahne oldu ve ciddi can kayıpları yaşandı. Yanukoviç'in bu kararı almasının ardında Rusya'nın Ukrayna üzerindeki baskısının önemli derecede rolü olduğu yönünde ciddi bir kanaat oluşmuştur. Gösterilerin ve çatışmaların yoğunlaşması üzerine devlet başkanı Yanukoviç istifa etmiş ve ülkeyi terk etmiştir. Bunun üzerine Ukrayna'da yeni bir hükümet oluşturulmuştur. Yaşanan bu olaylar Rusya tarafından Ukrayna'nın meşru hükümetini devirmeye yönelik planlı ve organize bir girişim olarak değerlendirilmiş ve Rusya bu duruma tepki göstermiştir. Mevcut çatışma ve kaos ortamında Rusya'nın Ukrayna sınırları içerisinde yaşayan Rus azınlıkları koruma sorumluluğu bulunduğu dile getirilmiştir. Ukrayna içerisinde başlayan çatışma ve kargaşa ortamında, Kırım'da bulunan Rusların güvenliklerini sağlama gerekçesi ile Rusya Kırım'a silahlı kuvvetlerini sokmuştur. Rusya Kırım'da kontrolü ele geçirmiş ve yeni bir hükümet kurulmuştur. 
Kırım Parlamentosu 11 Mart 2014 tarihinde Kırım'ın bağımsızlığını ilan etmiş, ardından da 16 Mart 2014'de yapılan referandumla da Rusya Federasyonu'na katılma kararı alınmıştır. Referanduma katılım oranı yüzde seksenin üzerinde olmuş ve \% 95'in üzerinde bir oyla da Kırım'ın Rusya Federasyonu'na katılımı yönünde karar çıkmıştır. Referandum ve çıkan sonuç Ukrayna merkezi hükümeti ve uluslararası toplum tarafından yasal ve meşru olarak kabul edilmemiştir.

Kırım'ın Rusya tarafından ilhak edilmesinden sonra, Ukrayna'nın doğu bölümlerinde yer alan Luhansk, Donetsk gibi şehirlerinde de Rusya yanlıları tarafından ayaklanmalar başlatılmıştır. Ukrayna merkezi hükümetinin ayrılıkçı güçlere silahla karşılık vermesi sonucu ülke bugün bir nevi iç savaş ve çatışma eşiğine gelmiștir. Bu durum Kırım krizinden sonra Ukrayna'nın ulusal egemenliğini ve toprak bütünlügünü ciddi manada tehdit eden bir durum yaratmıştır. Krizin sonlandırılmasına dair somut bir gelişme henüz kaydedilememiştir.

Bebler'in ifadesiyle, Kırım'ın Rusya tarafından ilhak edilmesi, uluslararası hukukun tüm yönleri ile ihlal edilmesi anlamına gelmektedir. Kırım'ın Rusya'ya katılması, BM Şartına, 1975 tarihli Helsinki Nihai Senedine, 1994 tarihli Budapaşte Memorandumuna ve Rusya Federasyonu ile Ukrayna arasında 1997'de imzalanan Dostluk ve İşbirliği Antlaşması'na aykırıdır. Bu durum Ukrayna'nın egemenliğini, toprak ve sınır bütünlügünü doğrudan ihlal etmiştir. Rusya Federasyonu ikili ve çok taraflı uluslararası antlaşmalar bakımından uluslararası hukuktan kaynaklanan tüm yükümlülüklerini ihlal etmiştir (Bebler, 2015: 44-45).

Sovyetler Birliği'nin varlığının 1991'de resmi olarak sona ermesinden sonra Ukrayna, Rusya Federasyonu'ndan sonra Sovyet Cumhuriyetleri arasında ikinci büyük nükleer cephaneye sahip ülke durumunda idi. Bu dönemde Ukrayna'nın nükleer silahlardan arındırılması, uluslararası toplumun öncelikli gündem maddelerinden birisi olmuştur. Bu bağlamda, 1994 yılında Ukrayna, Rusya Federasyonu, ABD ve Birleşik Krallık arasında, Ukrayna'nın nükleer silahlardan arındırılmasına ilişkin "Budapaşte Memorandumu" imzalanmıştır. Söz konusu belge ile "Ukrayna nükleer silahlarını elden çıkarmasına karş11ık, Batılı devletler ve Rusya, Ukrayna'nın toprak bütünlüğ̈̈nü ve siyasi bağımsızlığını tehdit edecek eylemlerde ve güç kullanımında bulunmayacaklarını taahhüt etmişlerdir". Buna ek olarak, "imzacı devletler birbirlerinin topraklarını askeri işgal ya da hukuksuz güç kullanımının konusu yapmayacaklarını ve toprakların işgali ve kendisine karşı hukuksuz güç kullanımını yasal saymayacakları konusunda güvence vermişlerdir" (Anlar, 2014: 208).

Batının genel algısı, Rusya'nın Ukrayna'da Kırım üzerinden sergilediği davranışın hem uluslararası hukuka hem uluslararası güvenliğe hem de liberal Batılı değerlere karşı ciddi bir meydan okuma olduğu yönündedir. Sonuç itibariyle, Kırım krizi özelde Ukrayna ve Rusya arasında genel olarak da tüm Doğu Avrupa'yı etkileyecek bir yeni çatışma alanı olarak ortaya çıkmıştır Bebler, 2015: 52-53). Rusya'nın Kırım'ı kendi topraklarına katması, Rus azınlıkların yaşadığı diğer eski Sovyet cumhuriyetlerinde de Ukrayna'dakine benzer senaryoların yaşanmasına dair endişeleri artırmıştır (Bebler, 2015: 51).

Ukrayna'da hükümeti protesto gösterileri ile başlayıp Kırım'ın Rusya'ya ilhakı ile sonuçlanan sürecin analizini yapmak, Ukrayna'nın iç politikası bakımından önem taşımaktadır. Zira, Kırım Krizi ile başlayan süreç, Ukrayna'nın iç demokratik konsolidasyonunu sağlama konusunda ciddi bir engel teşkil etmiş ve ülkenin kırılganlığını önemli derecede artırmıştır. Soğuk Savaş döneminde, temel olarak Sovyet tehdidine karşın kurulmuş olan NATO'nun, Soğuk Savaş'in sona ermesine rağmen varlığını devam ettirmesi ve özellikle de 1990'l yılların sonlarından itibaren eski Varşova Paktı üyelerini ve Sovyet Cumhuriyetlerini de içerecek şekilde doğuya doğru genişlemesi Rusya'yı ciddi anlamda rahatsız etmiştir. Rusya, NATO ve AB genişlemeleri aracılı̆̆ıyla Avrupa-Atlantik İttifakı tarafından yeni bir çevrelenme ve kuşatılma siyasetine tabi tutulduğu algısına sahip olmuştur. Rusya'nın, Batı'nın bu stratejisine yanıtı, eski Sovyet Cumhuriyetlerindeki kontrol alanını ve hegemonyasını tahakküm etme ve küresel bağlamda da 
Avrupa-Atlantik blokuna karşı Avrasya Birliğini projesini hayata geçirme girişimleri ile şekillenmektedir. Rusya, NATO'nun doğuya kendi sınırlarına doğru genişlemesini kendi güvenliği bakımından çok ciddi bir tehdit olarak değerlendirmiş ve bu tehdide karşın etkin yanıtlar verme arayış1 içine girmiştir (Demir, 2014: 181). Rusya'nın yeniden bir küresel aktör olma yolundaki hedefleri gözetildiğinde, Ukrayna'nın geleceğini hangi blok yanında tanımlayacağı çok büyük önem taşımaktadır. Rusya için temel hedef, jeopolitik bakımdan oldukça hassas bir coğrafyada yer alan Ukrayna'nın yönünü Rusya ile yapacağı yakın ittifaklık ilişkileri çerçevesinde belirlemesidir.

Soğuk Savaş sonrası dönemde, Batı'nın Karadeniz coğrafyasına yönelik artan angajmanı, bu bağlamda özellikle Bulgaristan ve Romanya'nın NATO üyesi olmaları, bu iki ülkenin ABD’ye topraklarında askeri üsler kurmasına izin vermesi, Ukrayna ve Gürcistan'da Batı ile yakın ilişkilerden yana olan hükümetlerin iktidara gelmeleri ve bu iki ülkenin NATO üyeliklerinin gündeme gelmesi, Karadeniz coğrafyasının Rusya ile Batı arasında yeniden bir rekabet alanı olarak ortaya çıkmasına neden olmuştur. Rusya, Karadeniz' de Batı tarafından çevrelendiği yönünde bir algıya sahip olmuştur (Çomak vd., 2014: 141-142). Karadeniz, Rusya için enerji nakil hatları bakımıdan büyük önem arz etmektedir. Karadeniz, Avrasya çıkışı doğal gaz boru hatlarının Avrupa'ya ulaşmasında temel bir enerji koridoru işlevi görmektedir. Rusya, Batı'nın, Karadeniz ve özellikle de Ukrayna üzerinden kendisine yönelik kuşatma stratejisine, bölgede hegemon gücünü tekrar tesis etme amaçlı girişimlerle yanıt vermeye çalışmıştır. Bu çerçevede Rusya, Avrasyacılığı esas alan bir strateji ile NATO’nun doğuya genişlemesini durdurma politikası izlemeye başlamıştır. 2008'de Gürcistan ile savaş ve 2014'de de Kırım'ın ilhakı ile Gürcistan ve Ukrayna'nın Batı ile olan yakın ilişkilerine bir set çekme politikası gütmüştür (Çomak vd., 2014: 142-143).

Ukrayna'nın muhtemel NATO üyeliği ve Avrupa-Atlantik kurumlarıyla yakın ilişkiler geliştirmesi Rusya'yı rahatsız etmiştir. Ukrayna'nın AB ve NATO üyelikleri aracılığıyla Batı İttifak sistemine entegre olması ihtimaline karşı Rusya siyasi, ekonomik ve askeri başta olmak üzere elindeki tüm araçları kullanarak Ukrayna'nın dış politika yönünü etkileme çabası içerisinde olmuştur Rusya Ukrayna'da yapılan seçimlerde Rus yanlısı adayları desteklemiştir. Viktor Yanukoviç bu bağlamda Rusya'nın da desteği ile 2010-2014 yılları arasında devlet başkanlığı görevini yürütmüştür. Yanukoviç döneminde Ukrayna, daha önce ilan edilen NATO üyeliği hedefinden vazgeçtiğini açıklamış, Rusya ile 2010 yılında imzalanan bir antlaşma ile de 2042 yılına kadar Rusya'nın Karadeniz Filosunu Sivastopol'da bulundurmasın razı olmuştur (Çomak vd., 2014: 154-155).

Soğuk Savaş'ın bitimi ile birlikte Ukrayna'nın siyasi bağımsızlığını elde etmesi, Rusya tarafından bir türlü kabullenilememiştir. Ukrayna'nın yeni bağımsız bir devlet olması Rusya tarafından çok büyük bir kayıp olarak değerlendirilmiştir. Ukrayna, Soğuk Savaş'ın ardından bağımsızlığını kazandığı günden bu yana ülke içi siyasi istikrarsızlıklar ve çalkantılarla yüz yüze kalmıştır. Bu bağlamda, sahip olduğu jeopolitik ve jeostratejik konum itibariyle, Ukrayna, bölgesel düzeyin ötesinde özellikle büyük güçler arasında küresel bir rekabet ve mücadele sahasına dönüşmüştür. Rusya ile Batı dünyası arasında stratejik öneme haiz bir geçiş noktası olması nedeniyle, Ukrayna sürekli kontrol altında tutulmak istenen bir ülke konumuna gelmiştir. Ukrayna üzerinde şekillenen Rusya-Batı rekabeti zaman zaman ülkenin bir çatışma alanına dönmesine neden olmaktadır. Özellikle, Kırım'ın Rusya'ya ilhakı sonrasında Ukrayna'da çatışma ve iç savaş boyutuna ulaşan gelişmeler hem Ukrayna'nın ulusal güvenliğini hem de genel anlamda Doğu Avrupa'nın ve Karadeniz havzasının güvenliğini ve istikrarını ciddi şekilde tehdit eder hale gelmiştir.

2013 yılının sonlarına doğru patlak veren ve 2014 Martında Kırım'ın Rusya'ya ilhakı ile sonuçlanan Ukrayna ve Rusya arasındaki krizin en temel nedenlerinden birisi, Ukrayna'nın Soğuk Savaş'ın bitiminden itibaren "Batı ile Rusya arasında yaşadığ 1 tarihi parçalanmışlıktır". Batı ve Rusya arasında Ukrayna üzerinden yaşanan hâkimiyet ve kontrol kurma mücadelesi, Ukrayna'nın iç politikada çok kırılgan bir devlet haline gelmesine neden olmuştur. Ülkedeki siyasi ve ideolojik 
ayrışmaların ve kutuplaşmaların temelde Batı ve Rus yanlılığı ş̧eklinde ortaya çıktı̆̆ görülmektedir. "Ukrayna'daki asıl çekişme Ukrayna milliyetçiliği ve doğu Slav milliyetçiliği arasında cereyan etmektedir. Etnik Ukrayna milliyetçiliği, reformları ve Batı ile bütünleşmeyi savunurken, Slav milliyetçiliği reformlara ve Batı ile bütünleşmeye mesafelidir" (Kuşçu, 2014: $311)$.

Rusya'nın Soğuk Savaş sonrası dönemde eski Sovyet coğrafyasında izlediği siyasetin temeli, bu alanda Avrupa-Atlantik ittifakının etkili olmaması üzerinde dayanmaktadır. Rusya, 1993 y1lında ilan edilen "Yakın Çevre Doktrini" kapsamında eski Sovyet cumhuriyetlerinin ABD ve AB'nin kontrolüne girmelerini kendi ulusal çıkarlarına ciddi bir tehdit olarak değerlendirmiş ve Batı'nın bu ülkelere yönelik entegrasyon politikalarını aşılmaması gereken kırmızı çizgileri olarak ilan etmiştir (Anlar, 2014: 216).

Ukrayna devlet başkanı Viktor Yanukoviç'in AB ile Doğu Ortaklı̆̆ı Anlaşması'nı imzalamaktan son anda vazgeçmesi ile birlikte başkent Kiev'de başlayan toplumsal gösteriler, Rusya tarafından Ukrayna'da seçilmiş meşru bir hükümeti devirmeye yönelik bir hareket olarak değerlendirilmiştir. Bayraklı'nın ifadesiyle, Rusya, eski Sovyet cumhuriyetlerindeki bu tür ayaklanmaları, "Batı'nın Rusya'yı izole etmek ve çevrelemek için Rusya'nın çevresindeki ülkelerde planladığı devrimler dizisinin bir parçası olduğuna inanmaktadır”. Rusya kendi nüfuz ve etkinlik alanı olarak gördüğü eski Sovyet Cumhuriyetlerinde, Batı'nın insan hakları, özgür ve adil seçimler ve demokrasi gibi unsurlar vasıtasıyla bu ülkelerin iç işlerini manipüle etme ve bu ülkeler üzerinde kontrol sağlama amacı güttüğü kanısındadır (Bayraklı, 2014: 2).

Erol'un ifadesiyle,

Ukrayna krizinin ortaya çıkmasının en önemli nedenlerinden birisi Rusya'nın Ukrayna'ya dönük jeopolitik ve jeostratejik hassasiyetleridir. Moskova açısından Ukrayna ve Kırım, Rusya'nın Güneye Doğru Politikasının ayrılmaz bir parçasıdır. Rusya Kırım'ı ve bu bağlamda Ukrayna'yı gözden çıkardığı takdirde: Karadeniz'i; Baltıklardan Hazar'a kadar uzanan geniş bir hat üzerindeki tampon bölgeyi ve dolayısıyla da bölgesel inisiyatifini; Avrasya Birliği’ni hedef alan Gümrük Birliği Projesini; Yakın çevresi ve bu bağlamda güvenlik ve imparatorluğun yeniden ihyası anlamına gelen Yakın Çevre Politikasını kaybedeceğini; enerji güvenliği bağlamında ciddi bir zafiyete uğrayacağını düşünmektedir (Erol, 2014: 5-6).

Özbay'a göre, Rusya'nın Ukrayna meselesinde işi Kırım'ın ilhakına kadar ileri götürecek derecede sert tepki vermesinin temel nedeni "Moskova'nın bazı kırmızı çizgilerinin açıkça ihlal edildiği ve çıkarlarının tehlikeye düştüğü algısının oluşmasıdır". Moskova eski Sovyet coğrafyasına yönelik jeopolitik ve jeostratejik planlarının bozulacağını düşündüğünden Ukrayna'daki toplumsal gösterilere böyle sert bir tepkide bulunmuştur (Özbay, 2014: 8-9).

Rusya özellikle 2000'li yılların başından itibaren Doğu Avrupa'da ve eski Sovyet coğrafyasında hegemon güç pozisyonunu tekrar kurma siyaseti izlemektedir. Bu kapsamda Ukrayna ve Ukrayna'nın tercihinin hangi yönde olacağı, Rusya'nın oluşturmak istediği Avrasya Birliği Projesi bakımından çok büyük önem taşımaktadır. Rusya için, tarihsel ve kültürel bağlar, coğrafi büyüklük, jeopolitik konum gibi hususlar dikkate alındığında, Ukrayna Avrasya Birliği içerisinde mutlaka yer almalıdır. Ukrayna'nın tercihi kendisinin ötesinde, “Avrasya Birliği'ne davet edilecek diğer eski Sovyet ülkeleri üzerinde de olumlu ve teşvik edici bir etkiye sahip olacaktır". Rusya'nın bu noktadaki temel amacı, Ukrayna'yı Avrupa-Atlantik blokuna kaptırmamaktır (Özbay, 2014: 9).

Rusya, Ukrayna ve özellikle de Kırım'a, birçok açıdan ama en önemlisi de kendisinin küresel planları açısından çok önem atfetmektedir. Ukrayna ve Kırım'da, Rusya'nın jeopolitik ve jeostratejik anlamda hassasiyetleri mevcuttur. Rusya'nın, eski Sovyet coğrafyasında etki ve kontrol sahibi olabilme, Avrupa-Atlantik İttifakı karşısında dengeleyici bir blok olarak Avrasya Birliği projesini gerçekleştirme ve bu bağlamda uluslararası politikada yeniden küresel bir oyuncu 
statüsüne kavuşabilme, Soğuk Savaş’ın bitimi ile Karadeniz'de kaybettiği gücü ve etkinliği tekrar kazanabilme hedefleri bakımından, Ukrayna, Rusya için çok büyük önem teşkil etmektedir. Bu çerçevede, Ukrayna mutlaka Rusya'nın kontrolü altında olmalı, dış politikada yönünü Rusya'dan yana belirlemelidir. Ukrayna'nın Rusya yanlısı bir dış politika izlemesi, Rusya'nın enerji güvenliği bakımından da önem taşımaktadır. Zira, Ukrayna, Rusya'nın enerji ihracatında kilit öneme sahip transit bir ülkedir. Enerji kaynaklarının Batı'ya transferinde bir geçiş koridoru işlevi görmektedir.

Bu noktada, Kırım'ın hem genel olarak hem de Rusya açısından taşıdığı öneme değinmek anlamlı olacaktır. Kırım, Sovyetler Birliği'nin dağılması sonrasında Ukrayna sınırları içerisinde özerk yönetime sahip bir cumhuriyet olarak ortaya çıkmıştır. "Kırım Yarımadası, Karadeniz'e kuzeyden hâkim olmaya elverişli bir coğrafi konuma sahiptir". Kırım'a hâkim olan güç, yarımadanın gerek doğu-batı gerekse kuzey-güney doğrultusunda Karadeniz'de stratejik açından üstünlük sağlayabilmektedir. Bunun yanında, "Kırım yarımadası Karadeniz'in doğu, güney ve batı kıyılarına yakınlığı nedeniyle, Kafkasya, Türkiye ve Doğu Avrupa'nın güvenliği açısından da hassas bir bölgedir". Son dönemlerde Kırım açıklarında tespit edilen doğal gaz yatakları da dikkate alındığında, Kırım'ın kontrolünün sadece stratejik açından değil aynı zamanda ekonomik bakımdan da çok önemli olduğu söylenebilir (Çomak vd., 2014: 157-158).

Rusya için Ukrayna'yı ve özellikle de Kırım'ı önemli kılan meselelerden birisi de, Soğuk Savaş döneminde Kırım'ın Sivastopol şehrinde konuşlandırılmış bulunan Rusya'nın Karadeniz Filosudur. Soğuk Savaş'ın bitimi ile birlikte, bağımsızlığını kazanan Ukrayna sınırlarında kalan bu deniz üssünün geleceğinin ne olacağı sorusu 1990'lı yıllar boyunca Rusya ile Ukrayna arasında ciddi bir anlaşmazlık konusu olmuştur. 1997 yılında imzalanan "Paylaşım Antlaşması" ile Rusya’nın askeri deniz üssünün varlığı 2017 yılına kadar uzatılmıştır. 2010 yılında imzalanan yeni bir antlaşma ile de Rusya'nın Karadeniz Filosunun 2042 yılına kadar Sivastopol'de konuşlu kalması konusunda her iki ülke mutabık kalmıştır.

Kelkitli’in ifade ettiği üzere,

Kırım, Sovyetler Birliği için tıpkı Çarlık Rusyası döneminde olduğu gibi Azak Denizi ve Karadeniz üzerinden sıcak denizlere ulaşmak için kilit önemde olmuş, Sovyetler Kırım'daki donanma ve askeri varlıkları sayesinde Karadeniz'de NATO'yu dengelemeyi başarmışlardır (Kelkitli, 2014: 293). Sivastopol Rusya'nın sıcak denizlere açılan tek üssüdür. Sivastopol'dan Karadeniz Filosu'na ait gemiler Boğazlar'ı geçip bir gün içinde Akdeniz’e ulaşabilmekte böylece Rusya'nın Balkanlar, Doğu Akdeniz ve Ortadoğu'daki nüfuzunun ve gücünün artmasına önemli katkıda bulunmaktadırlar. Tarihi, askeri ve jeopolitik faktörler, Karadeniz Filosu ve onun konuşlandığı Sivastopol şehrini ve Kırım yarımadasını Rusya açısından vazgeçilmez kılmaktadır. Karadeniz filosu, Rusya'nın Karadeniz bölgesinde üstünlük kurmasını sağlamakta, ülkenin güney sınırlarını korumakta ve Rusya'nın çevre bölgeleri etkileyebilmesi açısından kaldıraç vazifesi görmektedir (Kelkitli, 2014: 296).

Rusya için Ukrayna ve Kırım jeopolitik bakımdan çok büyük önem taşımaktadır. Bu bağlamda, Bayraklı'ya göre, "Kırım Yarımadası, Rus donanmasının Karadeniz filosunun üs bölgesi olması açısından, Rusya'nın Karadeniz ve Akdeniz siyaseti için vazgeçilmez olarak görülmektedir" (Bayrakl1, 2014: 2).

Kırım, Rusya açısından enerji kaynakları bakımından da önem taşımaktadır. Son yıllarda Kırım etrafında keşfedilen doğal gaz yatakları yarımadayı stratejik bakımdan daha da önemli bir hale getirmiştir. Kırım'ın Rusya'ya ilhakı sonrasında, yarımadanın münhasır ekonomik bölgesinde yer alan doğal gaz rezervlerinin kullanım hakkı Rusya'nın olmuştur. Ukrayna'nın Rusya'ya enerji alanında bağımlılı̆̆ı söz konusudur. Ancak Kırım Yarımadası'nın kaybedilmesi, enerji kaynaklarını çeşitlendirme ve Rusya'ya olan bağımlılı̆̆ azaltma siyaseti izleyen Ukrayna için büyük bir dezavantaj oluşturmuştur. 
Ukrayna ve Kırım'1 Rusya için farklı kılan unsurlardan birisi de Ukrayna'da ve özellikle de Kırım'da yoğun oranda Rus azınlığın yaşamalarıdır. Kırım'ın demografik yapısına bakıldığında, nüfusun yaklaşık yüzde 60'ını Rusların, yüzde 25'ini Ukraynalıların ve yüzde 13'ünü de Kırım Tatarları'nın oluşturduğu görülmektedir. Soğuk Savaş sonrası dönemde, Rus dış politikasının en temel parametlerinden birisi, Rusya Federasyonu dışındaki ülkelerde, özellikle ve çoğunlukla da eski Sovyet Cumhuriyetlerinde yaşayan Rus azınlıkların haklarının sonuna kadar korunacağıdır. Bu bağlamda, Rus azınlıkların "etnik ve kültürel kimliğini muhafaza etmek ve tarihi anavatan ile bağlantılarını sürdürmek ve yaşadıkları ülkelerde halklarını daha etkin korumak amacıyla örgütler kurmalarına katkıda bulunulacağı belirtilmiştir". Rusya bu tür destek ve yardım faaliyetlerini Kırım'da yaşayan etnik Rusları organize etmek bakımından önemli bir enstrüman olarak kullanmıştır (Kelkitli, 2014: 297). Çünkü Kırım, Rusya açısından tarihi olarak her zaman Rusya'nın bir parçasıdır ve Rusya'nın Ukrayna'da ve Kırım'da yaşayan Rusların temel hak ve özgülüklerini koruma sorumluluğu vardır. Rusya için, 2004'den itibaren Ukrayna'da yaşanan olaylar, etnik Rusların asimilasyonuna dönük hedefler içermektedir. Ukrayna'da ve Kırım'da yaşayan Rusların her türlü dil ve tarih bilinçlerinin geliştirilmesi hususunda Rusya her zaman Rus azınlıkların yanında olacaktır (Kuşçu, 2014: 312). Kuş̧̧u'nun ifadesi ile 'Rusya'nın vatandaşlarını korumak için ahlaki ve yasal sorumlulukları bulunmaktadır. Zira Sovyetler Birliği’nin dağılması sonrası farklı ülkelerin sınırları içinde kalan Rus diasporasının haklarını korumak Rusya'nın en doğal hakkıdır" (Kuş̧̧u, 2014: 313). Ukrayna'da başlayan ve yasal ve meşru hükümeti devirmeye dönük ayaklanma girişimleri, Ukrayna'da bir kaos ve çatışma ortamı yaratmıştır. Böylesi bir ortam da özellikle Ukrayna'nın doğusunda ve Kırım'da yoğun olarak yaşan Rus azınlıkların güvenliği için ciddi bir tehdit oluşturmaktadır (Kuşçu, 2014: 325).

Kırım'ın ötesinde, Ukrayna sınırları içerisinde Rusya ile bütünleşmek isteyen ayrılıkçı bölgelerin varlığı, Rusya'ya, Ukrayna'nın iç işlerine müdahale edebilme imkânını verecektir. Zira, Rusya, Rus azınlıkların güvenliğini gerekçe göstererek, diğer ülkelerin iç işlerine sıklıkla müdahale etme yolunu seçmektedir. Bir başka ifadeyle, Rusya kendi toprakları dışında yaşayan Rus azınlıkları, bulundukları ülkelere karşı dış politikada bir manipülasyon aracı olarak kullanma yoluna gidebilmektedir.

Baharçiçek ve Ağır'a göre, Kırım işgalinin ve ilhakının Rusya açısından temel amacı, Karadeniz'deki Rusya'ya ait Karadeniz Filosu'nun devamlılığını garanti altına almak ve Ukrayna'nın Avrupa-Atlantik bloku ile yakınlaşmasını engellemek, bu bağlamda da orta ve uzun vadede Ukrayna'nın özellikle NATO üyesi olmasını önlemektir (Baharçiçek \& Ağır, 2015: 35).

Kardaş'a göre ise, Ukrayna krizinin ve Kırım'ın Rusya'ya ilhakının en önemli nedeni, uluslararası sistemi ve devletler arası ilişkileri düzenleyen en temel ilkelerden biri olan "toprak bütünlüğ̈̈ ve sınırların değişmezliğgi" ilkelerinin uluslararası toplum tarafindan Ukrayna özelinde çiğnenmesidir. İşin daha da ileri boyutunu oluşturan husus ise, ilhakı gerçekleştiren Rusya ile ABD, Ukrayna ve Birleşik Krallık arasında 1994 yılında Ukrayna'nın toprak bütünlüğünü garanti eden Budapeşte Memorandumu'na rağmen Rusya'nın böyle bir eylemde bulunması ve uluslararası toplumun da sınırlı yaptırımlar ötesinde bu eyleme sessiz kalmasıdır. Kardaş, bu noktada küresel güvenlik yönetişiminde ortaya çıkan boşluğa dikkat çekmektedir. Uluslararası toplumun kendi içinde bir dağınıklığı söz konusudur ve yine ABD önderliğindeki uluslararası toplumun uluslararası alandaki temel norm ihlallerini cezalandıracak bir iradeyi gösterememesi söz konusudur. Böyle bir ortamdan cesaret alan Rusya eski Sovyet coğrafyasına dönük revizyonist bir politika izlemek yolunu seçmiştir (Kardaş, 2014: 5-6).

Özbay’a göre, "Rusya Kırımı işgal ederek hem Ukrayna'nın egemenliğine hem de uluslararası sisteme açıç̧a meydan okumuştur" (Özbay, 2014: 10). Erol'un ifadesi ile, "UkraynaKırım krizinin patlak vermesi, başta ABD olmak üzere Batı ve Rusya arasında Avrasya merkezli yeni bir güç mücadelesinin başlangıcı demektir" (Erol, 2014: 5). Ukrayna krizi sonrasında Kırım'ın Rusya tarafından işgali ve ilhakı, Avrupa-Atlantik ittifakı ile Rusya arasında güç mücadelesi 
bakımından çok ciddi bir kırılma yaratmış, hatta bu yeni durum "Yeni Soğuk Savaş" veya "İkinci Soğuk Savaş” dönemi olarak da adlandırılmıştır (Erol, 2014: 2).

Özbay’ın ifadesiyle, “Kırım krizi Soğuk Savaş'ın bitiminden sonra yaşanan en ciddi uluslararası boyutlu krizlerden birisidir. Bir başka ifadeyle, Kırım krizi Avrupa/Atlantik bloku ile Avrasya bloku çekişmesinin tamamen gün yüzüne çıktığını göstermiştił” (Özbay, 2014: 8). Rusya, özellikle 2000'li yılların başlarından itibaren, Avrupa-Atlantik bloku tarafından jeopolitik bir çevreleme ve kuşatma altına alındığı algısına sahip olmuş ve bu nedenle de Ukrayna özelinde Kırım üzerinden Batı dünyasına etkili ve şiddetli bir cevap vermek istemiştir (Özbay, 2014: 10).

Kırım krizi hem Ukrayna'nın iç istikrarı ve güvenliğini hem de Doğu Avrupa'nın bölgesel güvenliğini ciddi anlamda tehdit etme potansiyeline sahip bir konudur. Ukrayna'nın bugün itibariyle içerisinde bulunduğu iç çatışma ve kaos ortamı, ülkenin demokratikleşmesinin önündeki en önemli engellerden birisini oluşturmaktadır. Ukrayna, içte demokratik konsolidasyonu sağlayacak bir barış ve istikrar ortamından uzaktır. Ukrayna ve Kırım üzerinden gelişen kriz ortamı, Kırım'da yaşayan Kırım Tatarları'nın güvenliklerini de doğrudan tehdit edici bir boyut taşımaktadır.

Demokrasiye geçiş noktasında Batılı devletler ile entegrasyonu arttırma çabasında olan Doğu Avrupa ülkelerinden birisi de Moldova'dır. Sovyetler Birliği'nin Ermenistan'dan sonra en küçük ikinci cumhuriyeti olan Moldova 27 Ağustos 1991'de bağımsızlığını ilan etmiştir. Enerji ihtiyaçlarını karşılamada çok büyük oranda dışa bağımlı olan Moldova, bağımsızlık sonrasında diğer eski Sovyet cumhuriyetleri gibi ekonomik gerileme, siyasi istikrarsızlık, ayrılıkçı siyasi-etnik nitelikli çatışma ve Rusya Federasyonu ile sorunlu ilişkiler gibi meydan okumalarla karşılaşmıştır. Moldova diğer eski Sovyet Cumhuriyetlerinde olduğu gibi demokratikleşme ve serbest piyasa ekonomisine geçiş ve dönüşüm süreçleri yaşamaktadır.

Moldova'nın etnik yapısına bakıldığında ülke nüfusunun çeşitli etnik gruplardan meydana geldiği dikkat çekmektedir. Moldovalıların yanı sıra, Ruslar, Ukraynalılar, Bulgarlar ve Gagavuz Türkleri ülke nüfusunun yaklaşık \% 35'lik bölümünü oluşturmaktadır. Soğuk Savaş'ın sona ermesi ile birlikte her etnik grubun kendi siyasi, etnik ve sosyo-kültürel taleplerini öne sürmesi ve bu etnik gruplar arasındaki gerilim ve çatışmalar, bağımsızlık sonrası dönemde Moldova'nın karşılaştığı en önemli meydan okuma olmuştur (Fane, 1993: 137). Bu bağlamda Moldova 1990'ların başından itibaren ülkenin doğu kısmında Dinyester nehri ile Moldova-Ukrayna sinırı arasında kalan Transdinyester bölgesinde baş gösteren ayrılıkçı bir çatışma ile karşı karşıyadır. $\mathrm{Bu}$ sorun Moldova'nın iç ve dış politikasını doğrudan etkilemektedir. Bu çatışma hem Moldova'nın ulusal güvenliği hem de bölgenin genel güvenliği için önem arz etmektedir.

Moldova bağımsız bir devlet olduğu tarihten bugüne kadar sınırları içindeki Transdinyester bölgesi üzerinde egemenliğini kuramamış ve Transdinyester'de 'de facto' bir devlet 1990'lı yılların başından bu yana varlığını sürdüre gelmiştir. Bir başka ifadeyle, Moldova'nın ulus devlet ve ulusal kimlik oluşumu Rusya destekli Transdinyester ayrılıkçı bölge üzerinde devlet egemenliğini sağlayamaması nedeniyle sürekli bir tehditle karşı karşıya olmuştur. Ekonomik bakımdan çeşitli zorluklarla karşı karşıya olmasının yanısıra ayrılıkçı Transdinyester bölgesinin silah, uyuşturucu, insan kaçakçılığı ve diğer yasadışı ekonomik faaliyetler için adeta bir cennet olması Moldova'nın ekonomik gelişim göstermesini de zorlaştırmaktadır (Stent, 2007a: 8-10).

Bugün itibariyle Transdinyester sorunu çözülebilmiş değildir. Transdinyester sorunu literatürde "Çözümü Dondurulmuş Çatışma" (Frozen/Protracted Conflicts) olarak adlandırılmaktadır. Sorunun çözümsüz kalmasının nedenleri arasında etnik farklılıklara dayalı olarak izlenen politikalar, Transdinyester'de 'de facto' bir devletin ortaya çıkmış ve varlığını sürdürüyor olması, Moldova'nın sosyo-ekonomik anlamda az gelişmişliği ve ülkedeki demokratik kurumların zayıflığı gibi faktörler yer alsa da, sorunun çözümüne giden yolu tıkayan en önemli husus bölgedeki ve çatışmadaki Rusya faktörüdür. Rusya, Transdinyester sorunu aracıllğıyla 
bölgede etkisini sürdürme ve Moldova topraklarındaki askeri varlığı aracıllğı ile de bölgeyi jeostratejik bir araç olarak kullanma eğilimindedir.

Moldova merkezi yönetiminin ülke bütünlüğüne ilişkin bu sorunu çözüme ulaştırmada başarısız olması, Moldova'nın aynı zamanda ülke içinde daha demokratik bir devlet haline gelmesini ve Batı ile işbirliği yapmasını engellemektedir. Stent'e göre gelecekte devam etmesi muhtemel gözüken senaryo, Rusya'nın Transdinyester sorununun çözümü için pek istekli olmayacağı ve Transdinyester ile bağlarını güçlendireceği yönündedir. Bu durumda sorunun çözümünde ortaya çıkan açmaz, tıkanıklık devam edecek ve Transdinyester Moldova sınırları içinde 'de facto' bağımsız bir devlet olarak kalmaya devam edecektir (Stent, 2007a: 15).

Soğuk Savaş döneminde Moldova dili, Kiril alfabesinin kullanılması ve önemli oranda Rusça kelime aktarımıyla Sovyet Rusya tarafından Romence'den farklılaştııılmaya çalışılmıştır. Soğuk Savaş döneminde, Sovyetlerin ana argümanı Moldovalıların Romanya topraklarında yaşayan Romenlerden tamamıyla farklı bir etnik grup veya ulus olduğu ve aynı şekilde konuşulan dilin de yukarıda belirtildiği üzere Romence'den tamamıla farklı bir dil olduğu şeklinde idi. Nitekim Moldova'daki bu dil meselesi 1989-1991 yıllarında ülkenin bağımsızlığına giden süreci etkileyen en önemli faktörlerden birisi olarak karşımıza çıkmaktadır (Solchanyk, 1990: 176). O dönemde tarihçiler, dil bilimciler ve edebiyatçılar, Sovyetler Birliği tarafından, Romenlerin ve Moldovalıların tarihsel ve kültürel anlamda iki farklı ulus olduklarını ispat etmek için özellikle teşvik edilmişlerdir. O dönemdeki teze göre Moldovalıların konuştukları dil Romence'den farklı bir dildi. Soğuk Savaş döneminde Moskova'nın temel amacı Moldovalıları Romenlerden etnik olarak farklılaştıracak yeni bir Moldovalı kimliği inşa etmek olmuştur (Bruchis, 1996: 23). Bu tarihsel arka plan çerçevesinde, 1980'li yılların sonlarında, Moldova'nın yeni bağımsız bir devlet olarak ortaya çıkması sancılı bir sürece sahne olmuştur. Bu dönemde Moldova'da yaşayan ve Moldova dilini konuşan nüfus Sovyetler Birliği'nden ayrılarak bağımsızlıklarını kazanma yönünde politikalar izlerken, diğer taraftan Moldova sınırları içinde Transdinyester'de yaşayan ve Rusça konuşan nüfus ile Türkçe konuşan Gagavuzlar Moldova içerisinde ayrılıkçı cumhuriyetlerini ilan etmişlerdir.

1994 yılında yapılan parlamento seçimlerinde Rusya yanlısı Demokratik Köylü Partisi mecliste çoğunluğu elde etmiştir. $\mathrm{Bu}$ tarihten itibaren Moldova dış politikada oryantasyonunu Rusya'ya yoğunlaştırmıştır ve 1994'de Bağımsız Devletler Topluluğu'na üye olmuştur. 1996 y1lında Rusya yanlısı Peter Lucinschi'nin devlet başkanı seçilmesinden sonra Moldova ile Rusya arasında özellikle ekonomik ilişkiler yoğunlaşmıştır. 2000 sonrasında ise Moldova ile Rusya arasındaki ekonomik ilişkiler kötüleşmeye başlamıştır. Bu durum Rusya'nın Moldova'ya ihraç ettiği enerji kaynaklarının fiyatını artırması ve 2006 yılında Moldova'da üretilen șarapların ithalatına sağlık gerekçesi ile yasak getirmesinden kaynaklanmıştır. Bu yasağın ardından Moldova özellikle ekonomik anlamda Rusya'dan uzaklaşarak $\mathrm{AB}$ ile daha yakın ilişkiler kurmaya odaklanmıştır. Bu bağlamda Moldova Rusya, Kazakistan, Ukrayna ve Beyaz Rusya arasında kurulan "Ortak Ekonomik Bölge” yapılanmasına dâhil olmamıştır (Roper, 2008b: 85).

1998 yılında Moldova ile AB arasında "Ortaklık ve İşbirliği Anlaşması”" imzalanmıştır. Bu anlaşma ile $\mathrm{AB}$ ve Moldova arasında daha yakın işbirliğinin sağlanmasına yönelik resmi bir yapı oluşturulmuştur. Moldova ülke içinde karşılaştığı sorunlar nedeniyle $A B$ ile ilişkilerini çok geliştirememiştir. Moldova zaman zaman $\mathrm{AB}$ üyeliğinin birincil dış politika önceliği olduğunu dile getirse dahi 1990'lı yıllar boyunca Avrupa ile bütünleşme yolunda önemli bir gelişme kaydedememiştir. Moldova'nın iç politikasında gözlemlenen farklı politikalar ve düşünceler ülkenin dış politikada hangi doğrultuda bir strateji izleyeceği konusunda bölünmelere yol açmaktadır. Moldova siyasi yöneticileri ülkelerinin Batı yanlısı mı yoksa Rusya yanlısı mı bir politika izleyeceği konusunda ikiye bölünmüş durumdadırlar (Roper, 2008b: 87-88).

Moldova'da 2001 yılında yapılan parlamento seçiminden, oyların \% 50'sinden fazlasını alan ve meclisteki sandalyelerin yaklaşık \% 70'ini elde eden Moldova Komünist Partisi galip 
ayrılmıştır. Bu seçimler sonrasında pek çok analizci devlet başkanı Vladimir Voronin liderliğinde Moldova'nın BDT ile daha sıkı bir biçimde entegre olacağı ve ülkenin daha fazla Rus etki alanına gireceği öngörüsünde bulunmuşlardır. Fakat 2001 sonrası dönemde Moldova AB ve AB üyesi devletlerle diplomatik ve ekonomik bağlantılarını artırmıştır. Bu yakınlaşmanın neticesinde Şubat 2005'de Moldova ile AB arasında "Eylem Planı" imzalanmıştır. Eylem Planı çerçevesinde Moldova ile $\mathrm{AB}$ arasında koordinasyon sağlanması ve Moldova ulusal yasalarının $\mathrm{AB}$ mevzuatı ile uyumlu hale getirilmesi amaçlanmıştır. Eylem Planı, Moldova ile AB arasındaki ekonomik bağların genişlemesine de katkıda bulunmuştur (Roper, 2008b: 79-80). Moldova özellikle 2005 sonrasında Avrupa ile daha yakın ilişkiler geliştirmiştir. Ancak Rusya'ya enerji kaynakları bakımından olan bağımlılığı ile Rusya'nın özellikle Transdinyester bölgesi aracılığıyla Moldova üzerindeki siyasi ve askeri kontrolü, Moldova'nın Batı ile Rusya arasında dengeli bir politika izlemesini zorunlu kılmaktadır. Moldova toplumu ülkelerinin AB ve NATO'ya üyeliklerini desteklemektedir. Ancak Roper'e göre, AB ve Batı dünyası Moldova'ya daha büyük siyasi ve ekonomik destekler sağlamadığı sürece Moldova'nın her zaman için Rusya yanlısı bir dış politika izleme olasılığı vardır. Ülke nüfusunun çoğunluğu ve Batı yanlısı siyasi elitler Batı ile yakın işbirliğine dayalı bir strateji izlenmesinden yana olmakla beraber Rusya, özellikle Komünist Partisi içinde Moldova için halen daha güvenilir bir ortak olarak görülmektedir. Sonuç olarak Moldova bugün Batı ile Doğu arasında bir başka ifadeyle $\mathrm{AB}, \mathrm{ABD}$ ve Rusya arasında sıkışmış durumdadır (Roper, 2008b: 93-94).

2001 y1lının sonlarında Moldova hükümeti Romanya Tarihi dersinin Moldova Tarihi olarak değiştirilmesini ve aynı zamanda Rusçanın zorunlu eğitim dili olmasını teklif etmiştir. Aralık 2001'de, 2002 yılının Ocak ayından itibaren uygulamaya konmak üzere Rusçanın tüm eğitim kurumlarında zorunlu dil dersi olarak verilmesi kabul edilmiştir. Yeni hükümetin bu önerileri Moldova'da eğitimciler ve bilim adamları daha sonrasında da geniş halk kitlelerince şiddetli şekilde protesto edilmiştir. Moldova'nın iç politikasındaki gelişmelerin ülkenin dış politikasında özellikle de Batı ve Rusya ile olan ilişkileri üzerinde önemli etkileri bulunmaktadır. Örneğin 2001 yılından itibaren eğitim ve dil konusu Moldova'nın iç politikasında ana meseleler olarak ortaya çıkmış ve aynı zamanda bu konular ülkenin dış politikada jeo-stratejik yöneliminin belirlenmesi çerçevesinde Moldovalı kimliğinin tanımlanmasına yönelik olarak çeşitli gruplar tarafından kullanılmıştır. İktidarının ilk yıllarında Komünist Partisi Rusçanın kullanımını ve Moldova'nın BDT ile daha sıkı entegrasyonunu savunurken, muhalefet partileri Moldova dilinin kullanımını ve Moldova'nın Avrupalı kurumlarla ve uluslararası örgütlerle daha yakın işbirliği gerçekleştirmesi gerektiğini savunmuşlardır.

Sonuç olarak, eğitim ve dil konuları üzerinden Moldova ulusal kimliğine dair yapılan tartışmaların, asıl olarak ülkenin dış politika alanında oryantasyonunun ne yönde olacağ konusu ile doğrudan bağlantılı olduğu görülmektedir. Ülkedeki Batı yanlısı muhalefet partilerine göre Moldova bir Avrupa ülkesidir ve Batılı kurumlarla sıkı bir entegrasyon politikası izlemelidir. Komünist Partisi'nin geleneksel görüşüne göre ise Moldova, Rusya ve BDT ile daha yakın ilişkiler içerisinde olmalıdır. Buna paralel olarak, Rus dilinin özellikle eğitim alanında kullanımı ve ülkenin Rusya'nın domine ettiği kurumlar ve örgütlenmeler içerisinde olması Moldova için en iyi seçimdir (Roper, 2008b: 88-90). Bu durum Moldova toplumunun iç ve dış politika alanlarında kutuplaştı̆̆ını açıkça göstermektedir.

\section{Rusya Federasyonu'nun Bölge Ülkelerine Yönelik Dış Politikası}

Doğu Avrupa'nın siyaset boyutu üzerinden incelemesi yapılmaya çalışılırken, bölgenin en belirleyici dinamiklerinden birisi olan Rusya'nın bölge ülkeleri ile ilişkilerinin değerlendirilmesi büyük önem taşımaktadır. Soğuk Savaş'ın sona ermesinden hemen sonra Rusya Federasyonu ülke içinde siyasi ve ekonomik reformları gerçekleştirmek için Atlantikçi olarak adlandırılan Batı yanlısı ve Batı ile işbirliğine dayalı bir dış politika izlemiştir. Batı, Rusya için doğal bir müttefik olarak görülmüştür. Rusya'nın Batı merkezli siyasi ve ekonomik kurumlara katılımının sağlanması 
hedef olarak belirlenmiştir. Rusya Federasyonu'nun ilk dış işleri bakanı Andrei Kozyrev Rus dış politikasını Batı ile işbirliğine dayalı olarak yürütmek istemiştir. Ancak Rus dış politikasındaki Batı yönelimi milliyetçi ve muhalif siyasi ve askeri çevrelerden gelen yoğun eleştiriler neticesinde 1992 yılının ortalarından itibaren değişmeye başlamıştır. Bu eleştirilerin en önemli yanı Soğuk Savaş sonrasında Rusya Federasyonu'nun "Yakın Çevre" (Near Abroad Policy) olarak tabir edilen eski Sovyet coğrafyasını ihmal ettiği ve bu bölge için tutarlı bir politika izlemediği yönünde idi. O dönemde 'Yakın Çevre'nin ihmal edilmesi suretiyle Rus ulusal çıkarlarına aykırı davranıldı ğı ve eski Sovyet Cumhuriyetlerinde yaşayan yaklaşık 25 milyon Rusun haklarının korunmadığ ileri sürülmüştür (Birgerson, 2002: 67-68). Sonuç olarak, 1990'l1 yılların başlarında Rusya, Batı yanlısı ve Batı ile işbirliğine dayalı bir dış politika izlemesine rağmen, 1992 yılından itibaren Rus siyasi ve askeri çevrelerinde eski Sovyet coğrafyasının önemi ve esas olarak bu bölgeye ağırlık veren bir dıș politika oluşturulması konusunda uzlaşmaya varılmıştır (Birgerson, 2002: 65). Bu bağlamda, Rusya'nın 1990'lı yılların başlarında Batı ile yakın işbirliğine önem veren politikaları değişmeye başlamıştır. Bu politika değişikliği Doğu Avrupa'daki eski Sovyet Cumhuriyetlerinin veya bir başka ifadeyle yeni bağımsız devletlerin Rusya açısından önem kazanmasına yol açmıştır.

Rusya bölge ülkelerinden özellikle Ukrayna ve Beyaz Rusya ile yakın tarihi ve kültürel ilişkilere sahiptir. Sovyet Federal Anlaşması ile cumhuriyet statüleri belirlenen Ukraynalılar ve Beyaz Ruslar, Ruslarla başta Doğu Slav dili kullanımı olmak üzere birçok ortak noktaya sahip olmaları nedeniyle Soğuk Savaş döneminde siyaset ve bürokrasi alanlarında önemli pozisyonlar elde edebilmişlerdir. Kültürel yakınlık ve benzerliğin Ukrayna ve Beyaz Rusya'da bulunan Rus nüfusuyla birleşmesi bu Cumhuriyetlerde başta dil olmak üzere birçok alanda merkezden Ruslaştırma faaliyetlerinin rahatlıkla yürütülmesine imkân vermiştir (Solchanyk, 1990: 185). Rusça, Sovyetler Birliği'nin 'lingua franca'sı olduğu için, diğer Sovyet Cumhuriyetlerinde olduğu gibi Ukrayna, Moldova ve Beyaz Rusya'da sosyal yaşamda herkes Rusçayı belli bir derecede konuşmak ve anlamak zorunda idi. Rusça orduda, federal birimlerde ve komünist partisinin resmi organlarında resmi dildi (Solchanyk, 1990: 172). Tarihsel ve kültürel yakınlığa bağlı olarak Rusya, Soğuk Savaş sonrası dönemde Ukrayna, Moldova ve Beyaz Rusya'yı bağımsız egemen devletler olarak görmek istememiş ve bu ülkelerdeki gelişmeleri kendi açısından hem iç hem de dış politika konuları olarak değerlendirme eğiliminde olmuştur.

Bu çerçevede Rusya'nın BDT çatısı altında Ukrayna, Beyaz Rusya ve Moldova ile ilişkileri Rus dış politikasının temel önceliklerinden birisi olmuştur. Bu ülkelerin yer aldığı bölge Rusya için hayati çıkarlar ifade etmektedir. Bu durum özellikle 1993 yılından itibaren farklı siyasi seviyelerde dile getirilen "Yakın Çevre Politikası" başlığı altında ifadesini bulmuştur. Eski Sovyet coğrafyasında Batılı güçlerin askeri ve siyasi olarak egemenlik kurmalarının engellenmesi Rus dış politikasının ana hedeflerinden birisi olarak ilan edilmiștir (Mikhelson, 2002: 98-99). Rusya ekonomik, siyasi, askeri ve kültürel araçları kullanmak suretiyle Doğu Avrupa'nın genelinde etki ve kontrol kurmak istemektedir. Rusya'nın dış politikası temel olarak bölge ülkelerinin AvrupaAtlantik eksenli güvenlik ittifak sisteminin dışında tutulmaları üzerine odaklanmıştır (Mikhelson, 2002: 112-113).

Orta ve Doğu Avrupa'da komünist rejimlerin yıkılması ve Varşova Paktı'nın dağılmasıyla birlikte, Rusya Federasyonu, eski uydu devletler ve eski Sovyet Cumhuriyetleri üzerinde kontrolü sağlamak için kullandığı resmi mekanizmalardan yoksun kalmıştır. Buna karşın Rusya, Doğu Avrupa ülkelerine yönelik olarak izlemiş olduğu politikaları hayata geçirebilmek adına birtakım araçlara da sahiptir. Her şeyden önce, Rusya ile bu eski Sovyet Cumhuriyetleri arasında halen çok güçlü, tarihsel, dilsel ve kültürel bağlar ve ilişkiler mevcuttur. Doğu Avrupa'da yer alan eski Sovyet Cumhuriyetleri ile Rusya arasındaki ekonomik ve ticari bağlantılar çok yönlüdür. Bunlara ek olarak Rusya, Doğu Avrupa ülkelerindeki askeri varlığını devam ettirmektedir. Doğu Avrupa ülkelerindeki Rus askeri varlığı Moldova ve Beyaz Rusya'da önemli oranda mevcuttur. Rusya'nın Moldova sınırları içindeki Transdinyester'de ve Beyaz Rusya'da askeri birlikleri bulunmaktadır (Stent, 2007a: 12). Rusya, Transdinyester'de konuşlu bulunan Rus birlikleri aracılığıyla Moldova iç 
politikası üzerinde etki sağlayabilmektedir. Moldova'daki Rus askeri varlığı aynı zamanda Transdinyester'deki 'de facto' devletin varlığının devamlılığını sağlamaktadır. Diğer yandan Beyaz Rusya, Rusya’ya kendi topraklarında askeri üsler kurması için izin vermiştir (Mangott, 2007: 285). Sonuç olarak, askeri araçlar Rusya'ya bu ülkelerde kontrollü demokrasilerin sürdürülebilmesi ve bu ülkeler üzerindeki Rus etkisinin ve kontrolünün devamının sağlanması için olanaklar sağlamaktadır.

Rusya, Batılı devletlerin ve uluslararası örgütlerin Doğu Avrupa'ya yönelik politikalarını ve stratejilerini kendi ulusal güvenliğine ve bölgesel güvenliğe bir tehdit olarak değerlendirmekte ve bölgede Batı etkisine karşı mücadele etmektedir. Kremline göre, $A B$ ve ABD'nin nihai amacı diğer Doğu Avrupa ülkelerinde olduğu gibi Rusya'da da renkli bir devrim organize ederek rejim değişikliği sağlamaktır (Stent, 2007a: 11). Rusya Ukrayna, Kırgızistan ve Gürcistan'da meydana gelen ve renkli devrimler olarak adlandırılan organizasyonların Batılı devletler tarafindan planlanıp düzenlendiği kanısındadır. Rusya bu devrimleri kendi güvenliğine ve istikrarına karşı potansiyel bir tehdit unsuru olarak değerlendirmektedir. Rusya'nın küresel düzeyde yeniden belirleyici roller üstlenmesine yönelik çabalarına karşın engeller yaratan $\mathrm{ABD}$, Rusya'nın eski Sovyet coğrafyasındaki özellikle de Doğu Avrupa ve Kafkasya'da meşru çıkar ve haklarını tanıma konusunda istekli değildir (Stent, 2007b: 428). Rusya'nın Doğu Avrupa'daki temel çıkarı, renkli devrim yaşamamış olan ülkelerdeki rejimlerin devamlılığını sağlamaktır. Rusya bu ülkelerden herhangi birinin başta NATO olmak üzere, Avrupa-Atlantik İttifak sisteminin bir parçası olmasını engelleme politikası izlemektedir. Rusya özellikle Ukrayna ve Gürcistan'ın NATO üyelikleri meselesini kendi güvenliğini doğrudan tehdit eden bir unsur olarak değerlendirmektedir (Stent, 2007a: 12). Rusya'nın bakış açısına göre, ABD'nin Ukrayna ile yakınlaşması, NATO ve Ukrayna arasında yoğunlaştırılmış diyalog ve Ukrayna'nın NATO üyeliği konusu, Rusya ile ABD arasındaki sorunlu ilişkileri daha da kötüye götürmektedir (Mangott, 2007: 279). Sonuç olarak, Rusya Batılı devletlerin Doğu Avrupa'daki jeo-politik ve jeo-ekonomik faaliyetleri aracılığıyla kendisinin eski Sovyet coğrafyasındaki hegemonyasını yeniden kurma amaçlı faaliyetlerini zayıflatmayı ve engellemeyi amaçladığını düşünmektedir.

Mangott'un ifadesi ile Rusya Batılı devletlerin bölgedeki politikalarını Doğu ile Batı arasında yeni bölünmeler yaratma ve Rusya'yı dışarıda bırakma çabaları olarak görmektedir. Rusya, Batılı devletlerin ve kurumların izlediği politikaların, Doğu Avrupa ülkelerinin yer aldığı coğrafyayı Rusya'nın etki alanından çıkarma amacı taşıdığını iddia etmektedir. Batılı devletlerin bu yöndeki stratejileri, Rusya'nın bakış açısına göre, hem kendisinin bölgedeki çıkarlarına hem de bölgenin genel güvenliğine ve istikrarına karşı bir tehdit unsuru oluşturmaktadır (Mangott, 2007: 276). Rusya, Batılı devletlerin Doğu Avrupa ülkelerindeki siyasi ve ekonomik elitleri Rusya’ya karş1 örgütleyerek, bölgede Rusya'nın etkinliğini azaltmay1 amaçladığı görüşündedir. Bu bağlamda, Rusya bugün Doğu Avrupa'yı kendi güvenlik alanı bakımından birincil derecede önemli görmektedir (Mangott, 2007: 280).

Sonuç olarak, Rusya'nın Doğu Avrupa ülkeleri için bugünkü eğilimlerini sürdürmeye devam etmesi durumunda bölgede mevcut durumun devamından yana olması, bölgede çözümü dondurulmuş çatışmaların, sorunların çözümsüzlüğünün devamından yana olması ve bölge ülkelerinin Avrupa-Atlantik güvenlik sistemine entegre olma çabalarını önleme hedefi güdeceği rahatlıkla söylenebilir. Bölge ülkelerinin Rusya'ya ekonomik ve özellikle enerji alanındaki bağımlılıkları ile bölge ülkelerindeki Rus askeri varlığı göz önüne alındığında, Rusya'nın Doğu Avrupa coğrafyasında her alanda önemli etkilere sahip olacağı ifade edilebilir (Stent, 2007a: 1-3). Rusya'nın bölgenin diğer ülkeleri üzerinde kurmaya çalıştı̆̆ hegemonya, Doğu Avrupa'nın en temel bölgesel dinamiklerinden birisidir.

\section{Sonuç}

Soğuk Savaş sonrası dönemde Doğu Avrupa ülkeleri siyaset, ekonomi ve güvenlikle ilgili alanlarda bir dönüşüm süreci yaşamaya başlamıştır. Siyasi açıdan bakıldığında bunlardan en 
önemlisi otoriter bir sistemden çok partili parlamenter demokrasiye geçiş, ekonomi perspektifinden bakıldığında ise merkezi planlı bir ekonomiden serbest piyasa ekonomisine geçiş süreçlerinin tamamlanmasıdır. Siyasi ve ekonomik alanlardaki değişim ve dönüşüm süreçlerinin bölge ülkelerinin dış ve güvenlik politikalarına birtakım önemli yansımaları da olmuştur. Bu dönüşüm süreci bugün halen devam etmektedir. Demokratik kurumların oluşturulması, rekabetçi ve açık bir piyasa ekonomisinin hayata geçirilmesi ve bunların yanında demokratik ve liberal normların benimsenmesi gibi konular Doğu Avrupa ülkelerinin gündeminde yoğun bir şekilde yer almaya devam etmektedir (Mangott, 2007: 262). Diğer yandan, Soğuk Savaş'ın sona ermesi ve Sovyetler Birliği'nin dağılması, özellikle Doğu Avrupa'da yeni istikrarsızlıkların, çatışma alanlarının ve yeni güvenlik risk ve tehditlerinin ortaya çıkmasına neden olmuştur. 1991 sonrasında bölge ülkelerinin siyasi-etnik içerikli krizlerle, ekonomik sorunlarla ve demokratik kurumların eksikliğinden kaynaklanan kurumsal zayıflıklarla mücadele ettiklerine tanık olunmaktadır.

Orta Avrupa'da bulunan eski Varşova Paktı ülkeleri Sovyet kontrolünden kurtulduktan sonra demokratik yönetimler ve ekonomi alanlarında ilerleme sağlanabilmesi için yönlerini Batı Avrupa'ya çevirmişlerdir. Orta Avrupa ülkeleri güvenlik politikalarını yine aynı şekilde AvrupaAtlantik ittifak sistemi içerisinde konumlandırmaya çalışarak AB ve NATO'ya üyelik perspektifleri takip etmişlerdir. Batılı devletler Soğuk Savaş'ın bitimi ile birlikte, Doğu Avrupa ülkelerinin liberal demokrasi ve ekonomik kalkınmayı sağlamak adına yapmaları gereken siyasi ve sosyo-ekonomik reformlar ile dönüşüm süreçleri için de bir model oluşturmuşlardır. Ancak Orta Avrupa ülkelerinin aksine, Doğu Avrupa'da bulunan ülkeler başta Rusya Federasyonu olmak üzere Moldova, Ukrayna ve Beyaz Rusya bugün için Batı merkezli güvenlik ve siyasi entegrasyon amaçlı uluslararası örgütlere üye olmaktan uzaktır. Bu durum Batı Avrupa ile bütünleşmeyi başaran Orta Avrupa ülkeleri ile Rusya ve Rusya'nın etkisi nedeniyle Batı ile mesafeli ilişkilere sahip olan Doğu Avrupa ülkeleri arasında yeni bir coğrafi bölünmeye yol açmaktadır. Bu husus literatürde "Avrupa-Atlantik güvenlik toplumunun içindekiler ve dışındakiler" şeklinde bir ayrımla dile getirilmektedir.

Doğu Avrupa ülkelerinden Ukrayna, Moldova ve Beyaz Rusya'nın gelecek dış politika yön/blok tercihleri temel olarak kendi seçimleri neticesinde belirlenecektir. Fakat görece olarak zayıf olan bu devletlerin siyasi gelecekleri, kendilerinin yanı sıra komşuları ve uluslararası politikanın başat aktörleri olan $A B$, Rusya ve $A B D$ tarafindan bu ülkelere yönelik olarak izlenecek politikalar tarafından da şekillenecektir. Rusya Federasyonu bölge ülkeleri üzerinde sahip olduğu siyasi, ekonomik, askeri ve kültürel araçlarla Doğu Avrupa'daki gelişmeleri önemli derecede etkileme gücü ve potansiyeline sahiptir (Stent, 2007a: 10-15). Schmidtke ve Yekelchyk, Ukrayna, Moldova ve Beyaz Rusya'nın yer aldığı coğrafyayı "Avrupa'nın son sınırı" şeklinde tanımlamaktadır. Literatürde sıklıkla ileri sürüldüğü gibi onlara göre de bu üç ülkenin yer aldığı coğrafya, $\mathrm{AB}$ ile uluslararası politikada ve eski Sovyet coğrafyasında yeniden etkinlik ve hâkimiyet kurmayı amaçlayan Rusya Federasyonu arasında bir güç mücadelesine sahne olmaktadır.

$\mathrm{Bu}$ çerçevede $\mathrm{AB}$, Doğu Avrupa ülkelerini içine alacak bir politika mı izleyecektir yoksa bu ülkeler yakın gelecekte zengin ve demokratik $\mathrm{AB}$ ile otoriter Avrasya coğrafyası arasında mı kalacaklardır? AB'nin sınırları Polonya-Ukrayna sınırında $\mathrm{m} 1$ bitecektir? Komünizmin sona ermesinden bu yana Doğu Avrupa ülkelerinin üye olmak istedikleri iki organizasyon olan NATO ve $A B$ 'nin kapıları Doğu Avrupa ülkelerine kapatılırsa, bu ülkeler için tam üyelik içermeyecek ancak bu ülkelerin gerekli siyasi, ekonomik ve sosyal reformları gerçekleştirebilmeleri için AB'nin Komşuluk Politikası'nın içerdiklerinin de ötesinde ne tür perspektifler verilebilir ya da ne tür vizyonlar ve yol haritaları çizilebilir? Üye olabilmek için gerekli kriterleri yerine getirseler dahi, bu ülkelerin Avrupa-Atlantik ittifak sisteminin dışında kalmaları ne tür sonuçlar ortaya çıkarabilir? Stent'e göre önümüzdeki dönemde cevabını arayacak en önemli sorular bunlardır. Yine Stent'e göre Ukrayna, Moldova ve Beyaz Rusya gibi Doğu Avrupa ülkeleri için yakın gelecekteki en iyi senaryo bu ülkelerin işleyen demokrasilere, şeffaf kurumlara ve yasalara sahip olarak, AvrupaAtlantik örgütlenmeleri ile de bir biçimde ilişki içinde olarak yollarına devam etmeleri şeklinde öngörülebilir. En kötü senaryo ise, bu ülkelerin belirtilen bu reformları ve dönüşümü 
başaramayarak, yolsuzluk ve yoksulluk sarmalı içinde kalarak hem bulundukları bölgenin hem de Avrupa'nın istikrarına ve güvenliğine potansiyel bir tehdit olarak kalmaya devam etmeleri şeklinde öngörülebilir.

Bölge ülkelerindeki demokratikleşmeye, çoğulcu bir toplumun oluşmasına ve hukuk devleti ilkesinin yerleştirilmesine dair ortaya çıkacak yeni gelişmeler hem Doğu Avrupa ülkelerinin siyasi geleceğini hem de bölge ülkeleri aracıllı̆ı ile diğer eski Sovyet Cumhuriyetlerinde meydana gelebilecek siyasi gelişmeleri doğrudan ve önemli derecede etkileme potansiyeline sahiptir (Stent, 2007a: 2-21). Doğu Avrupa ülkelerinin gelecekleri Avrupa kıtasının güvenliği bakımından da büyük önem taşımaktadır. Çünkü bu ülkeler Avrupa ve Avrasya'yı birbirine bağlayan önemli askeri, ulaşım ve enerji koridorları üzerinde yer almaktadır. Bugün AB'nin sınır komşusu olan Doğu Avrupa coğrafyasında baş gösteren birtakım yeni güvenlik problemleri tüm Avrupa'ya sıçrama potansiyeli olan riskler ve tehditler barındırmaktadır.

Sonuç olarak, Doğu Avrupa bölgesi sahip olduğu önemli jeo-politik ve jeo-stratejik konumu nedeniyle Rusya Federasyonu, $\mathrm{ABD}$ ve $\mathrm{AB}$ gibi küresel aktörlerin jeo-politik ve jeoekonomik çıkarlarının rekabetine sahne olmaktadır. Mangott'a göre, Doğu Avrupa ülkelerinin sadece Avrupa-Atlantik kurumlarının yeni doğu sınırlarını oluşturması veya Rusya'nın hegemonik gücünü yeniden kurmaya çalıştığı coğrafyanın batı sınırlarını oluşturması, genel anlamda Avrupa Kıtasının güvenliğine karşı bir tehdit oluşturmaktadır. Doğu Avrupa ülkeleri bu iki seçeneği ayrı ayrı hayata geçirme politikası izlememelidir. Çünkü Doğu Avrupa toplumlarına bakıldığında bu toplumların çok yönlü kimliklere sahip oldukları görülmektedir. Doğu Avrupa ülkelerinin bu çok yönlü kimlik birleşimi, batı ve doğu arasında yeni bölünmeler ve bariyerler inşa etmekten çok yeni köprüler kurmak için bir firsat olarak değerlendirilmelidir (Mangott, 2007: 275-276).

Doğu Avrupa bölgesi için siyasi değişim, dönüşüm süreçleri üzerinden yürütülen inceleme sonucunda, çalışmanın temel argümanı, Soğuk Savaş sonrası dönemde bölge ülkelerinin demokratikleşme bakımından oldukça sınırlı bir gelişim göstermiş olmaları ve bunun en temel nedenlerinden birisinin de Rusya'nın siyasi, ekonomik, ticari, askeri ve kültürel birtakım araçlarla bölge ülkeleri üzerinde doğrudan etkide bulunabilme kapasitesine sahip olmasıdır. Bölge ülkelerinden özellikle Rusya ve Beyaz Rusya'da komünizm sonrası dönemde demokratik dönüşüm süreçleri ciddi bir ilerleme kaydetmemiştir. Bu iki ülkede, otoriter eğilimli yönetimler varlıklarını devam ettirmişler ve demokrasi olacaksa da bunun kendi tarihsel kodlarına uygun ancak "kontrol altında" ve "yönetilen" bir demokrasi olabileceği düşüncesi ağırlık kazanmıştır. Ukrayna ve Moldova ise, diğer iki ülkeye nazaran demokratik dönüşüm açısından bir çaba içerisinde olmuşlar ancak bu ülkeler de özellikle dış politika yön tercihleri bakımından Batı ile Rusya arasında kalmaktan ve Rusya'nın bu ülkeler üzerinde siyasi, ekonomik, askeri, kültürel, sosyal ve tarihsel faktörlerle şekillenmiş etkileri nedeniyle demokratikleşme konusunda kayda değer bir ilerleme sağlayamamışlardır. Özellikle Ukrayna'nın ortak milli bir kimlik ve ulus bilinci tesis edememesi; buna ek olarak 2014'de Kırım'ın kaybedilmesi ve ardından da ülkenin doğu bölgelerinde bir iç çatışma ortamının oluşması; Moldova'da ise ayrilıkçı Transdinyester sorunu ve Moldova'da bulunan Sovyet döneminden kalma Rus askerleri ve askeri mühimmat nedeniyle bu iki ülkenin bu sorunlarla uğraşırken gerçek anlamda bir demokratikleşme sürecine yoğunlaşmaları çok mümkün olmamıştır. Bu noktada, özellikle Ukrayna için belirtilmesi gereken husus, ülkenin toplumsal olarak dış politikada tercih bakımından Avrupa-Atlantik bloku ve Rusya arasında bölünmüş bir görüntüye sahip olmasıdır. Doğu Avrupa ülkelerinden Ukrayna ve Moldova, kendileri ile tarihsel bağlamda yakın ilişkilere sahip olan Rusya'nın bölgeyi ve bu ülkeleri domine etme amaçlı politikaları nedeniyle içte demokratik konsolidasyonu gerçekleştirme konusunda başarılı olamamışlardır. Rusya'nın bölge ülkeleri üzerindeki etkisi ve kontrol kurma isteği, bölge ülkelerinin iç ve dış politikalarında oldukça kırılgan yapılara sahip olmaları sonucunu doğurmuştur. 


\section{Kaynakça}

Anlar, A. (2014). "Rusya ve Batı Arasında Ukrayna Krizi”. Uluslararası Politikada Ukrayna Krizi. (Der.) Hasret Çomak, Caner Sancaktar, Zafer Yıldırım. Beta. 191-220.

Arbatov, G. (1997). "Post-Cold War Challenges to Stability in Eastern Europe and the Former Soviet Union". The Search for Stability in Russia and the Former Soviet Bloc. (Eds.), David Carlton and Paul Ingram. Ashgate. 1-13

Astrov, V. \& Havlik, P. (2007). "Belarus, Ukraine and Moldova: Economic Developments and Integration Prospects". The New Eastern Europe: Ukraine, Belarus, Moldova. (Eds.) Daniel Hamilton and Gerhard Mangott. Center for Transatlantic Relations. 127-147.

Baharçiçek, A. \& Ağır, O. (2015). Kırım'ın Rusya Federasyonu'na Bağlanamsının Rusya'ya Komşu Ülkelere Olası Etkileri. Akademik Bakış Dergisi, 52, 29-47.

Baranovsky, V. (2000). A Part of Europe or Apart from Europe?. International Affairs, 76(3), 443458.

Bayraklı, E. (2014). Avrupa Birliği’nin Ukrayna Kriziyle İmtihanı. Seta Perspektif, 40.

Bebleri, A. (2015). Crimea and the Russian-Ukrainian Conflict. Romanian Journal of European Affairs, 15(1), 35-53.

Birgerson, S. M. (2002). After the Breakup of a Multi-Ethnic Empire. Preager.

Bruchis, M. (1996). The Republic of Moldavia from the Collapse of the Soviet Empire to the Restoration of the Russian Empire. Translated by Laura Treptow. East European Monographs.

Çomak, H., Sandıklı, A., Kaya, E., İsmayılov, E. (2014). "Karadeniz'de Yeni Gelişmeler, Ukrayna Krizi ve Türkiye". Uluslararası Politikada Ukrayna Krizi. (Der.) Hasret Çomak, Caner Sancaktar, Zafer Yıldırım. Beta. 137-167.

De Fraye, H. (1997). "Instabilities in the Former Soviet Union and Eastern Europe and the Role that OSCE Can Play". The Search for Stability in Russia and the Former Soviet Bloc. (Eds.) David Carlton and Paul Ingram. Ashgate. 167-190.

Demir, S. (2014). "Ukrayna Krizi: Yeni Küresel Politik Düzenin Başlangıcı". Uluslararası Politikada Ukrayna Krizi. (Der.) Hasret Çomak, Caner Sancaktar, Zafer Yıldırım. Beta. 169-190.

Donaldson, R. H. \& Nogee, J. L. (2005). The Foreign Policy of Russia: Changing Systems, Enduring Interests. M.E. Sharpe.

Erol, M. S. (2014). "Ukrayna-Kırım Krizi” Ya Da "İkinci Yalta Süreci”. Karadeniz Araştırmaları, $41,1-14$.

Fane, D. (1993). "Moldova: Breaking Loose from Moscow". Nation and Politics in the Soviet Successor States. (Eds.) Ian Bremmer and Ray Taras. Cambridge University Press. 121153.

Hamilton, D. \& Mangott, G. (Eds.). (2007). The New Eastern Europe: Ukraine, Belarus, Moldova. Center for Transatlantic Relations.

Hughes, J. \& Sasse, G. (2002). "Comparing Regional and Ethnic Conflicts in Post-Soviet Transition State". Ethnicity and Territory in the Former Soviet Union: Regions in Conflict. (Eds.) James Hughes and Gwendolyn Sasse. Frank Cass. 1-35. 
Kardaş, Ş. (2014). Türkiye ve Ukrayna Krizi: Suriye Krizi'nin İzdüşümleri. Ortadoğu Analiz, 6(62), 5-6.

Kelkitli, F. A. (2014). "Kırım: Rusya İçin Vazgeçilmez Yarımada". Uluslararası Politikada Ukrayna Krizi. (Der.) Hasret Çomak, Caner Sancaktar, Zafer Yıldırım. Beta. 290-308.

King, C. (1998). Moldovan Identity and the Politics of Pan-Romanianism. Slavic Review, 53(2), 345-368.

Kuşçu, I. (2014). “Kırım’ın Rusya'ya Katılımının Bölgesel ve Küresel Etkileri”. Uluslararası Politikada Ukrayna Krizi. (Der.) Hasret Çomak, Caner Sancaktar, Zafer Yıldırım. Beta. 309-334.

Kuzio, T. (2006a). Is Ukraine Part of Europe's Future?. The Washington Quarterly, 89-108.

Kuzio, T. (2007b). "Prospects for the Political and Economic Development of Ukraine". The New Eastern Europe: Ukraine, Belarus, Moldova. (Eds.) Daniel Hamilton and Gerhard Mangott. Center for Transatlantic Relations. 32-53.

Mangott, G. (2007). "Deconstructing a Region". The New Eastern Europe: Ukraine, Belarus, Moldova. (Eds.) Daniel Hamilton and Gerhard Mangott. Center for Transatlantic Relations. 261-286.

Marples, D. R. (1999). Belarus: a denationalized nation, Horwood Academic Publishers.

Özbay, F. (2014). Rusya'nın Ukrayna Politikası ve Kırım Hamlesi. 2023, 155, 8-11.

Roper, S. D. (2002a). "Regionalism in Moldova: The Case of Transdniestr and Gagauzia". Ethnicity and Territory in the Former Soviet Union: Regions in Conflict. (Eds.) James Hughes and Gwendolyn Sasse. Frank Cass. 101-122.

Roper, S. D. (2008b). "Post-Soviet Moldova's National Identity and Foreign Policy". Europe's Last Frontier? Belarus, Moldova and Ukraine between Russia and the European Union. (Eds.) Oliver Schmidtke and Serhy Yekelchyk. Palgrave Macmillan. 79-96.

Rudling, P. A. (2008). "Belarus in the Lukashenka Era: National Identity and Relations with Russia, Europe's Last Frontier?" Belarus, Moldova and Ukraine between Russia and the European Union. (Eds.) Oliver Schmidtke and Serhy Yekelchyk. Palgrave Macmillan. 5577.

Schmidtke, O. \& Yekelchyk, S. (2008). "Introduction". Europe's Last Frontier? Belarus, Moldova and Ukraine between Russia and the European Union. (Eds.) Oliver Schmidtke and Serhy Yekelchyk. Palgrave Macmillan. 1-7.

Solchanyk, R. (1990). "Ukraine, Belorussia, and Moldavia: Imperial Integration, Russification, and the Struggle for National Survival". The Nationalities Factor in Soviet Politics and Society. (Eds.) Lubomyr Hajda and Mark Beissinger. Westview Press. 175-203.

Stent, A. E. (2007a). "The Lands In Between: The New Eastern Europe in the Twenty-First Century". The New Eastern Europe: Ukraine, Belarus, Moldova. (Eds.) Daniel Hamilton and Gerhard Mangott. Center for Transatlantic Relations. 1-21.

Stent, A. E. (2007b). "Reluctant Europeans: Three Centuries of Russian Ambivalence Toward the West". Russian Foreign Policy in the Twenty-First Century and the Shadow of the Past. (Ed.) Robert Legvold. Columbia University Press. 393-441.

---, "Seçim İsyanına Demir Yumruk", Milliyet, 21 Aralı 2010, http://www.milliyet.com.tr/dunya/secim-isyanina-demir-yumruk-1328927 (Erişim Tarihi 02.05.2019). 